\title{
Permanências do urbanismo de colina como tradição luso-brasileira: os casos de Salvador e de São Paulo
}

\author{
Permanencies of hill urbanism as a Portuguese-Brazilian \\ tradition: the cases of Salvador and São Paulo
}

José Geraldo Simões Junior ${ }^{[0]}$, Candido Malta Campos ${ }^{[b]}$

[a] Arquiteto e urbanista pela Faculdade de Arquitetura e Urbanismo da Universidade de São Paulo (FAU/USP), doutor em Arquitetura e Urbanismo pela (FAU/USP), professor adjunto do Programa de Pós-Graduação em Arquitetura e Urbanismo da Universidade Presbiteriana Mackenzie, São Paulo, SP - Brasil, e-mail: jgsj@mackenzie.br

[b] Arquiteto e urbanista pela Faculdade de Arquitetura e Urbanismo da Universidade de São Paulo (FAU/USP), doutor em Arquitetura e Urbanismo pela (FAU/USP), professor adjunto do Programa de Pós-Graduação em Arquitetura e Urbanismo da Universidade Presbiteriana Mackenzie, São Paulo, SP - Brasil, e-mail: cmcn5@uol.com.br

\section{Resumo}

A partir da compreensão dos processos de ocupação das áreas de colina em cidades brasileiras e portuguesas, associados à tradição urbanística lusitana de fundar cidades em sítios elevados, buscamos identificar as principais características dessas áreas enquanto espaços privilegiados para o resgate de forte tradição presente em nossa cultura urbanística. Tomamos como exemplo dois casos paradigmáticos: Salvador e São Paulo. Primeiro núcleo urbano do Brasil fundado com status de cidade (1549), Salvador contou com plano constituído por traças e amostras, esboçando arruamento, muralhas e localização de edifícios públicos. A escolha do sítio fundacional, em sítio dominante, sobre atracadouro, constituindo a dualidade cidade alta/ cidade baixa, é marca da urbanística de colina praticada pelos portugueses em seu império colonial. Por sua vez, poucas cidades da América portuguesa tiveram destino tão ligado à implantação em colina como São Paulo. Até 1850 a vida urbana se concentrou nessa acrópole; o centro criado no início do século XX foi implantado sobre a mesma elevação; modernizações sucessivas mantiveram foco no núcleo primitivo. Essa insistência na transformação da área central apagou traços da ocupação de matriz luso-brasileira, alterando traçados, morfologia e volumetria, e ocultando a própria situação topográfica. Propomos aqui esforço de recuperação dos elementos morfológicos da ocupação original desses sítios e compreensão dos padrões urbanísticos que as caracterizavam; identificando impactos dessas práticas no desenho e configuração urbanos, tendo em vista a revalorização desses elementos históricos, muitas vezes obscurecidos por ocupações posteriores, visando recuperar a forte relação com o sítio original em acrópole que marcou essas cidades.

Palavras-chave: Urbanismo. Colina. Tradição luso-brasileira. Salvador. São Paulo. 


\section{Abstract}

By understanding the processes of urbanization of hill areas in Brazilian and Portuguese cities, associated to the Portuguese tradition of founding cities in elevated settings, we intend to identify major characteristics of these hilltop areas, as spaces where this strong tradition, present in our urban culture, can be traced. Two paradigmatic cases are studied: Salvador and São Paulo. First urban nucleus with city status founded in Brazil (1549), Salvador had an initial plan outlining street layout, walls and the location of public buildings. The choice of its site in an elevated, dominant setting, with the port at its base, constituting the "high city/low city" duality, marks the hilltop urbanism practiced by Portugal in its colonial empire. São Paulo's role in Portuguese America was also closely connected with its hilltop implantation. Until 1850 urban life was concentrated in the original acropolis; the downtown area created at the start of the 20th century was built over the same elevation; and urban modernization kept its focus on the primitive core. This insistence on transformation of the central nucleus erased traces of original Portuguese-Brazilian hilltop occupation, altering its layout, morphology, and skyline, and hiding the topography. We propose to recover morphologic elements from the original urbanization of these sites and understand the urban patterns that characterized them; identifying impacts of such practices on urban layouts and configurations, so as to recuperate historic elements, often eclipsed by later interventions, in order to recover the strong relation with the original acropolis site that marked these cities.

Keywords: Urbanism. Hill. Portuguese-Brazilian tradition. Salvador. São Paulo.

\section{Introdução}

Este trabalho se insere no projeto de pesquisa "Urbanismo de Colina: Uma Tradição LusoBrasileira", desenvolvido recentemente por docentes e discentes portugueses e brasileiros. Visa compreender os processos de ocupação inicial das áreas de colina nas cidades brasileiras e portuguesas associados a práticas da urbanística lusitana relativos à urbanização de sítios elevados. Objetiva compreender também suas permanências no que se refere à situação atual, identificando potenciais para sua valorização, uma vez que permitem a recuperação de traços de uma tradição fortemente associada à nossa cultura urbanística.

Razões de defesa, primordialmente, levaram colonizadores portugueses a aplicar, no Brasil, o princípio milenar de escolha de sítios elevados, protegidos por escarpas ou encostas íngremes, de preferência junto a pontos acessíveis por via marítima ou fluvial, para suas fundações urbanas. Reproduzia-se, assim, a dualidade cidade alta/cidade baixa, que associava a segurança da acrópole à conveniência do porto como paradigma da urbanística portuguesa. Os topos serviam para abrigar as funções residenciais, institucionais e religiosas, e os trechos ribeirinhos ou junto à orla marítima eram destinados às atividades portuárias e de comércio.
As primeiras etapas da pesquisa se iniciaram em Portugal, por meio da orientação de dissertações de mestrado desenvolvidas nas Universidades Técnica de Lisboa e de Coimbra, que enfatizaram aspectos morfológicos e físico-espaciais, em que medições de campo assumiam papel fundamental no processo de coleta de informações. No Brasil, a pesquisa procurou privilegiar o entendimento conceitual e histórico da cidade de colina, recorrendo a fontes secundárias de documentação. 0 levantamento bibliográfico foi extenso, coligido, organizado e estudado ao longo de vários anos de pesquisas anteriores sobre o tema da urbanística brasileira e ibero-americana. Em três seminários realizados entre Lisboa e São Paulo foram consolidadas as metodologias de trabalho entre os grupos de pesquisadores do Brasil e de Portugal.

A escolha dos casos de estudo foi pautada pela relevância e representatividade em relação à temática da cidade de colina. Os casos brasileiros inicialmente definidos são bastante emblemáticos neste sentido: Salvador, por ter sido a primeira capital e, portanto, cidade fundada com planejamento e estudo de implantação, na qual foi adotado o modelo tradicional - localização no interior de grande baía, porto seguro com águas tranquilas, fundação no alto de uma colina, a cavaleiro do porto, boas águas, bons pastos, terras agriculturáveis e área 
disponível para expansão urbana; São Paulo, fundada apenas cinco anos após Salvador, foi o primeiro núcleo urbano estabelecido fora da orla marítima, com interesse estratégico de controlar as rotas de penetração do interior. Apesar de não ter contado com "risco" como o de Salvador, foram aplicados os mesmos critérios de localização em acrópole para a cidade alta (colégio dos jesuítas), justaposta à zona do mercado junto ao Rio Tamanduateí.

Os demais casos estudados no âmbito do projeto (Rio de Janeiro e Ouro Preto, no Brasil; Óbidos, Alta de Coimbra e bairro da Alfama, Lisboa, em Portugal) também são representativos do processo de constituição da urbanística lusitana; mas seu detalhamento não cabe no presente artigo, fazendo parte, assim como Salvador e São Paulo, em versão estendida, do volume atualmente em preparação que reunirá os resultados do projeto como um todo.

\section{Salvador}

\section{Escolha do sítio e ocupação da colina}

Salvador foi o primeiro núcleo urbano do Brasil fundado com o status de cidade, em 1549, para inaugurar a implantação do Governo-Geral, concebida e projetada para ser a capital - ou Cabeça do Brasil, na expressão da época. Seu plano é atribuído a Miguel de Arruda, conselheiro de D. João III e seu mentor para questões urbanas, arquiteto-mor das obras reais realizadas em Portugal e em todo o império luso, que pouco antes havia projetado a cidade-fortaleza de Mazagão, na costa ocidental africana. Tais planos eram constituídos por traças e amostras, nas quais constava o esboço dos arruamentos, das muralhas e da localização dos edifícios públicos (MOREIRA, 2003).

0 critério de escolha do sítio fundacional, em cota dominante na paisagem, em ponto protegido junto à entrada da baía e com implantação de atracadouro, constituindo a dualidade cidade alta/ cidade baixa, é marca evidente da urbanística de colina praticada pelos portugueses em todo seu império colonial ao longo do século XVI. A capitania já havia tido um núcleo inicial de ocupação, menos protegido, Vila Velha, onde hoje é o Porto da Barra, mas este se revelou inadequado do ponto de vista do Governo-Geral (PITA, 1976).
O Regimento de Tomé de Souza possui indicadores sobre os critérios de escolha do sítio fundacional. Este não deveria se situar nas proximidades da Vila Velha, mas mais para dentro da baía, em local de melhor defesa; deveria abrigar uma fortaleza e permitir grande expansão futura. A definição precisa do local deveria se basear em indicações de pessoas locais, doutas e conhecedoras da região. Além disso, o local deveria ter bons ares, água e um bom porto. Após detalhado reconhecimento da baía, optou-se por um promontório em que uma escarpa de 60 metros protegesse um tabuleiro elevado, também salvaguardado ao fundo pelo vale do Ribeirão das Tripas e dos lados pelas gargantas do Taboão e da Barroquinha (UNIVERSIDADE FEDERAL DA BAHIA/FUNDAÇÃO GREGÓRIO DE MATOS, 1998).

0 traçado da cidade e a construção de seus elementos iniciais ficaram sob a responsabilidade de Luís Dias, um dos principais assessores de Tomé de Souza; Cavaleiro da Casa Real Portuguesa, distinção alcançada pelo bom desempenho em funções anteriores. Era o mestre de obras da cidade de Salvador, um dos cargos mais bem remunerados do GovernoGeral. Trouxe "traças e amostras" de Lisboa, que esboçavam o arruamento urbano desejável, porém sem rigidez excessiva, funcionando como orientação passível de adaptação às circunstâncias locais.

D. João III, no próprio Regimento do governador, lhe ordenava que seguisse fielmente as traças $e$ amostras que levais, decerto completadas por instruções orais e escritas dadas ao mestre Luis Dias. Esses perdidos planos seriam desenhos de pormenor (formato e dimensões das muralhas, perfil dos baluartes, plantas e alçados das casas e edifícios públicos) (MOREIRA, 2003, p. 39, grifo do autor).

A ocupação da colina histórica soteropolitana foi, desde sua origem marcada pela dualidade cidade baixa/cidade alta, comum à urbanística portuguesa, mas por outro lado, diferenciada em relação a muitas outras vilas fundadas no Brasil no século $\mathrm{XVI}$, dado o seu caráter estratégico de "cabeça do Brasil", capital política de imenso território a ser ocupado e defendido. Por esse motivo, seu projeto de implantação assume um caráter planificado, afinal Salvador representaria a terceira (após Lisboa e Goa), depois segunda, maior capital do império 
marítimo português, e merecia uma abordagem planejada, no espírito da disciplina renascentista.

Para a caracterização do perfil de ocupação da área histórica de Salvador, foi considerada como área objeto de estudo o perímetro delimitado pelo mapa do Conder (realizado a partir de voo em 1992, na escala 1:2000), com os limites definidos pelas áreas entre as igrejas de São Bento e Santo Antônio, e no sentido leste-oeste pelas ruas que seguem o alinhamento do sopé da encosta na cidade baixa (oeste), e pelas imediações da Baixa do Sapateiro na vertente leste. A evolução da ocupação da colina, ao longo de seus quase 460 anos de existência, pode ser estudada a partir de uma periodização definida por cinco momentos marcantes em sua estruturação espacial.

\section{9 a 1654: da fundação à expulsão dos holandeses}

A partir da definição do sítio fundacional, junto ao promontório, foram construídas defesas pelos quatro lados: ao norte e ao sul, as portas de Santa Luzia (São Bento) e de Santa Catarina (Carmo), assim como as duplas paliçadas na frente do mar, uma na cidade alta e outra na praia (UNIVERSIDADE FEDERAL DA BAHIA/FUNDAÇÃO GREGÓRIO DE MATOS, 1998). A primeira igreja foi na parte baixa, a da Conceição da Praia, situada junto aos armazéns e oficinas na área portuária. Na parte alta, Luís Dias mandou construir fortes muros de pau a pique, procedendo à abertura da praça principal (que seria o centro administrativo da colônia até 1763 , ladeada ao sul pelo Palácio dos Governadores, e a leste, pela Casa de Câmara e Cadeia, tendo ao centro o primeiro pelourinho); definiu os arruamentos seguindo as traças trazidas de Lisboa e iniciou a construção dos primeiros edifícios públicos.

Segundo Simas Filho, nos primeiros tempos eram duas as ligações da cidade alta com a cidade baixa: a primeira, a Ladeira da Conceição, aberta em 1549 e bastante íngreme, que partia da Praça Municipal e descia em dois lanços até a área da praia. A segunda, menos íngreme e mais adequada ao trânsito de carros de boi, construída em 1550, partindo da atual praça Castro Alves e seguindo pelas atuais ladeiras da Gameleira e da Preguiça (UNIVERSIDADE FEDERAL DA BAHIA/FUNDAÇÃO GREGÓRIO DE
MATOS, 1998). 0 desnível abrupto de 60 metros sempre foi problemático para o transporte de mercadorias. Assim, desde os primeiros tempos foram utilizados guindastes, rampas e contrapesos para vencer o declive.

No alto dessa colina soteropolitana desenvolveu-se a parte mais nobre da cidade, que concentrava os edifícios da administração pública, as sedes das ordens religiosas, as residências que abrigavam os "homens de bem" (pessoas do clero, da administração pública, militares, e comerciantes), além dos muros defensivos. Num momento seminal de expansão, até o final do primeiro século, os limites dessa ocupação na colina eram delimitados pelo posicionamento das igrejas de São Bento (ao sul), Carmo (ao norte), São Francisco (leste), e a encosta sobre o mar (oeste). A encosta era utilizada unicamente como local de passagem, através de duas ladeiras e um plano inclinado, que faziam a conexão com o porto e a cidade baixa.

Quanto à área conhecida hoje como Pelourinho, ou seja, o trecho entre o Terreiro de Jesus e a Igreja do Rosário dos Homens Pretos, seu traçado urbanístico já aparece nas reconstituições gráficas do século XVI, com uma convergência viária em direção a uma das sete portas da cidade, a do Carmo. Esta estava então situada justamente onde se localizava o pelourinho, instrumento de punição de escravos localizado em praça pública, hoje largo do mesmo nome em frente à Igreja do Rosário.

Esse trecho, entre os séculos XVII e XVIII, com o apogeu da economia baiana e a expansão das atividades portuárias - não mais limitada ao açúcar, mas também envolvendo tabaco, algodão, couro, café, ouro e diamantes -, se tornaria o bairro aristocrático de Salvador, abrigando inúmeros sobrados senhoriais de quatro e até cinco pavimentos e solares; conformando padrões e tipologias arquitetônicas que até hoje permanecem.

Nos primeiros anos, a cidade já apresentava indícios de expansão para o norte, atraída pela igreja dos jesuítas e a Santa Casa. No relato de Gabriel Soares, por volta de 1580 a primeira cerca foi eliminada, uma vez que a cidade ampliou-se consideravelmente: ao norte chegando até o Carmo, no rumo da Igreja de Santo Antonio; ao sul, pelas ruas Direita dos Mercadores (hoje Chile), da Ajuda, Pão de Lot (atual do Tesouro) e dos Capitães (hoje Rui Barbosa), chegando até o Mosteiro de São Bento; a 
leste, a colina era delimitada pelo conjunto dos franciscanos (UNIVERSIDADE FEDERAL DA BAHIA/ FUNDAÇÃO GREGÓRIO DE MATOS, 1998).

As quatro ilustrações comentadas a seguir, mostrando a evolução da cidade ao longo das primeiras décadas, sintetizam esse processo, mostrando que a instalação das ordens religiosas dos beneditinos, carmelitas e franciscanos, juntamente com a presença dos jesuítas, foi fator determinante na organização espacial e desenvolvimento da cidade.

Do século XVI, não há cartografias ou desenhos disponíveis, apenas relatos e cartas de viajantes e funcionários, assim como descrições constantes em normativas legais. Merecem destaque, além do regimento de Tomé de Souza, as cartas de Luís Dias (a Miguel de Arruda), as do padre Manoel da Nóbrega e os escritos de Gabriel Soares de Souza (1582-1585). Vale destacar o comentário de Manuel Teixeira:

Em Salvador da Baía encontramos uma síntese de múltiplas referências: vernáculas e eruditas, medievais e renascentistas, que moldaram a estrutura e os espaços da cidade. A estruturação de Salvador da Baía em cidade alta, dos poderes civis, militares e religiosos, e em cidade baixa, dos comerciantes e marinheiros, a existência de praças com funções distintas e o tipo de quarteirões que ainda encontramos numa primeira fase da malha urbana de Salvador são expressão dos modelos, ainda de origem medieval, que lhes estão na origem. Ao mesmo tempo, o planejamento regular da cidade alta e a malha ortogonal que se desenvolve em torno do Terreiro de Jesus, tendo nesta praça o seu elemento central, são expressão de modelos, de referências formais e de concepções de espaço urbano modernas que, por sua vez, constituem a matriz de desenvolvimentos posteriores (TEIXEIRA; VALLA, 1999, p. 227).

De 1599 até 1649 , a Bahia foi alvo de constantes ataques por parte dos holandeses. Nesse período, foram elaborados os primeiros documentos cartográficos sobre a cidade, em geral de autoria holandesa, como os de Claes Visscher (1624) e Hessel Gerritsz (1627), sendo relevantes também os trabalhos do cartógrafo português João Teixeira Albernaz (1605 e 1625). Nessa iconografia, há riqueza de informações sobre a ocupação da colina soteropolitana. Aparecem as construções mais antigas da cidade alta, entre as quais se destacam as torres dos beneditinos (ao sul) e dos carmelitas (ao norte). Na cidade baixa, armazéns da zona portuária e construções voltadas ao comércio. A encosta ainda permanece desocupada, só trespassada por algumas ladeiras e pelos dois planos inclinados.

\section{4 a 1808: consolidação da cidade colonial}

De meados do século XVII, com a Restauração da Coroa Portuguesa e a expulsão definitiva dos holandeses do Brasil e Angola, até a abertura dos portos por Dom João, Salvador vive seu apogeu enquanto maior porto do Atlântico Sul, pólo de rendoso comércio entre Brasil, África e a Metrópole. É também o apogeu da cidade alta e seus bairros centrais como depositários da riqueza que o comércio, o açúcar e logo o ouro concentravam na capital da colônia, posição que começou a declinar com a transferência da capital para o Rio de Janeiro no período pombalino (1763).

A área entre os conventos jesuítico, franciscano e carmelita, incluindo o atual Largo do Pelourinho, concentrava essa riqueza em igrejas, amplos conventos e inúmeras casas senhoriais, algumas ostentando certo requinte arquitetônico. Tornava-se o bairro aristocrático da cidade, em contraste com o centro administrativo em torno da Praça do Palácio e a faixa comercial da cidade baixa.

Este segundo período é rico em relatos e iconografias, destacando-se em 1801 o frontispício de Salvador por Luis dos Santos Vilhena. São também relevantes as ilustrações do viajante François Froger (1698), os relatos dos viajantes Francisco Coréal (1685), William Dampier (1699), Le Barbinais (1717), assim como as vistas elaboradas pelos engenheiros militares franceses João Massé (1715) e Amedée-François Frézier (1716), mostrando uma cidade em franco crescimento, com a zona baixa dominada por construções de maior porte voltadas ao florescente comércio portuário, já impactado pelo ciclo da mineração.

O século XVIII é também fecundo em descrições e narrativas, sobretudo a de Rocha Pita, publicada em Lisboa em 1730. Segundo sua descrição, em 1720, Salvador possuía seis mil casas, e mantinha ainda duas portas principais: uma ao norte e outra ao sul, definindo, na cidade alta, uma área 
cercada dentro da qual se situava a Igreja Matriz, o Palácio Episcopal, a Igreja e o Colégio dos Jesuítas, a Igreja e o Convento de São Francisco, as Igrejas da Misericórdia, de Nossa Senhora da Ajuda e de São Pedro dos Clérigos. Esse setor central compunha-se de seis bairros: o das Portas de São Bento, o de Nossa Senhora da Ajuda, o da Praça, o do Terreiro, o de São Francisco e o das Portas do Carmo. As praças eram duas: a do Palácio, quadrada com aproximadamente $55 \mathrm{~m}$ de lado, ladeada pelo Paço dos Generais, pela Casa da Moeda, pela Casa de Câmara e Cadeia e pela Casa da Relação; e o Terreiro de Jesus, retangular com aproximadamente 115 × 75 m (PITA, 1976).

A evolução da cidade pode ser acompanhada em detalhe em fontes iconográficas como os desenhos de José Antonio Caldas (1758), de José Azevedo Galeão (1785), de Manoel Rodrigues Teixeira (1786) e de José Joaquim Freire (1798); além das vistas constantes na obra "Notícias Soteropolitanas e Brasílicas", de Luís dos Santos Vilhena (1800), material coligido por Nestor Goulart Reis Filho e publicado em 2000 sob o título de "Imagens de Vilas e Cidades do Brasil Colonial", além de análises urbanísticas realizadas em publicação sobre o urbanismo barroco do Brasil (REIS FILHO, 1994).

\section{8 a 1912: intervenções}

sobre a estrutura colonial

Nesse período, registrou-se forte crescimento populacional e grande ampliação da área urbanizada, para muito além das portas consagradas no relato de Rocha Pita. Se em 1800 sua população era de aproximadamente 50 mil habitantes, em 1900 ela havia quadruplicado, dando origem a diversos núcleos de povoação nos arrabaldes (CENTRO HISTÓRICO DE SALVADOR, 2000).

0 perfil econômico da cidade alterou-se com a extinção do tráfico de escravos, em 1850, quando o capital mercantil começa a se diversificar e a indústria prospera, de tal forma que por volta de 1870 , Salvador continha o maior parque industrial do país. Obras de retificação viária, saneamento, implantação de infraestruturas de transporte e iluminação, embelezamentos urbanos, ajardinamentos de praças, e a organização e expansão da cidade baixa pautaram as intervenções oitocentistas (CENTRO HISTÓRICO DE SALVADOR, 2000).

A região do Pelourinho, na face norte da cidade alta, passou, ao longo do século XIX, por significativas mutações. Como parte mais valorizada da cidade, abrigou, até por volta de 1870, as residências senhoriais mais suntuosas, constituídas por sobrados de diversos andares ${ }^{1}$. No entanto, com as mudanças na economia e a abolição, foi empobrecendo e chegou ao final do século com muitos casarões já ocupados por cortiços (PINHEIRO, 2002).

0 foco das intervenções se deslocou para a cidade baixa, alargada por sucessivos aterros, ornada por grandes sobrados comerciais enfileirados, e acessada por novas vias, elevadores e planos inclinados. A área da encosta voltada para a baía passou a ser mais intensamente ocupada, com casarios implantados ao longo das ladeiras. São construídos o elevador hidráulico Lacerda (na Praça do Palácio) e a Ladeira da Montanha, ambos na década de 1870, e o elevador do Taboão e os planos inclinados de Gonçalves e do Pilar, na última década.

Os registros iconográficos constituídos por mapas de engenheiros militares são substituídos por fotografias: são de grande relevância as tomadas de cena em ruas da área central e as vistas ampliadas da fachada da cidade, realizadas na segunda metade do século XIX por Benjamim Mullock, Camillo Vedani, Guilherme Gaensly, Rodolfo Lindermann, J. Schleier e Marc Ferrez (FERREZ, 1988).

Selecionamos quatro imagens dessa época para análise e ilustração. A primeira delas, da autoria de Marc Ferrez, de 1875, apresenta uma panorâmica da área central vista da baía, fotografada a partir do Forte do Mar. Ferrez e Schleier registram também

\footnotetext{
${ }^{1}$ Ao longo dos séculos XVIII e XIX configura-se o apogeu da opulência vivida pela elite soteropolitana. Na cidade alta, os casarões da área histórica do Pelourinho são, a partir de 1850, preteridos por palacetes que vão sendo construídos ao longo do novo eixo de expansão da cidade, constituído pela Avenida Sete de Setembro e Corredor da Vitória. Nesses novos bairros, o estilo burguês do morar incorporará uma nova configuração espacial: lotes grandes, com recuos dos vizinhos, amplos quintais arborizados e residências ao estilo eclético europeu, adornadas com materiais de acabamento importados e sofisticado mobiliário. A esse cenário de vida dos "brancos da terra", contrapõe-se a miséria que predominava entre a imensa maioria da população, constituída por escravos, homens libertos e mulatos. A esse respeito, consultar a obra de Katia M. de Queirós Mattoso (2002).
} 
as obras de execução da Ladeira da Montanha, que seria o mais importante caminho de ligação entre cidade alta e baixa. Nessa época, a encosta marítima da colina naquele ponto (imediações da atual Praça Castro Alves) já mostra ocupação quase que inteiramente consolidada.

1912 a 1992: deslocamento da centralidade dominante e deterioração do centro histórico

No início do século XX, cidades brasileiras buscavam se reinserir de forma mais vantajosa nos circuitos do comércio internacional e passaram a fazer uso de intervenções urbanísticas saneadoras e modernizadoras, tentando apagar o passado colonial, considerado vergonhoso e atrasado. Dessa maneira, iniciativas de remodelação urbana foram empreendidas objetivando enfrentar graves problemas sanitários, implantar novas infraestruturas, ordenar as construções, ampliar o sistema viário e modernizar os portos. Visavam também gerar uma nova imagem para a cidade, atrelada a ideais estéticos europeus e burgueses. Quarteirões centrais de ruas estreitas e edifícios coloniais (muitos já abrigando cortiços) foram arrasados para viabilizar tais políticas modernizadoras, dando lugar a ruas alinhadas e alargadas, avenidas, praças, centros cívicos e edifícios modernos.

Salvador não escapou à regra e na década de 1910 passou por grandes obras de modernização, conduzidas pelo governador José Joaquim Seabra (1912-1916), que, dentre outros melhoramentos, remodelou o bairro da Sé; abriu a Avenida Sete de Setembro (unindo a Praça Castro Alves ao Farol da Barra e viabilizando a expansão da cidade no rumo sul); modernizou o porto e ampliou a área comercial na cidade baixa, por meio de grandes aterros e sua conexão aos bairros da zona norte.

No bairro da Sé, foi alargada a conexão entre a lateral da Catedral e a Praça Castro Alves, constituída pelas ruas da Misericórdia e Chile, esta última tornando-se a rua mais elegante - ladeada por construções em estilo eclético, com lojas chiques e confeitarias (PINHEIRO, 2002). Essa rua se integrava ao principal eixo de valorização imobiliária da cidade, formado na sequência pela Avenida Sete de Setembro e Corredor da Vitória, ligando o centro comercial à região sul, onde a elite que antes morava na região do Pelourinho iria se instalar, em palacetes com jardins e muita insolação, seguindo os princípios do higienismo.

A partir de meados do século XX, a cidade passou a sofrer impactos decorrentes da descoberta do petróleo no Recôncavo Baiano, recebendo grande afluxo migratório, fazendo sua população triplicar em trinta anos. Na área central, na cidade alta, acelerou-se o processo de encortiçamento e proletarização, agravado com o abandono da região pelas políticas públicas, de tal forma que, nos anos 1980, o patrimônio arquitetônico ali existente encontrava-se em perigo iminente de ruína.

Desde o final dos anos 1950, medidas esparsas já haviam sido tomadas pelo SPHAN, que em 1959 tombou algumas manchas nos bairros da Sé, Passo e Conceição da Praia. Mais tarde, em 1983, o Decreto Municipal n. 3289 definiu uma área de proteção rigorosa e de proteção contígua. No ano seguinte, foi homologado o tombamento federal numa extensa área definida como "Centro Histórico de Salvador", que em 1985 foi inscrita pela Unesco como Patrimônio Cultural da Humanidade (CENTRO HISTÓRICO DE SALVADOR, 2000).

\section{2 a 2012: recuperação e polêmica}

A partir de 1992, a área do Centro Histórico próxima ao Pelourinho passou a ser objeto de ambicioso programa de recuperação empreendido pelo governo estadual, para aproveitar seu potencial turístico. Iniciado de forma abrupta, com maciços investimentos em prazo curto, centenas de imóveis foram praticamente reconstruídos, inaugurando a primeira de sete etapas de intervenção que perduram até os dias atuais.

Esse programa, desde o início, recebeu pesadas críticas por parte de urbanistas e especialistas em preservação, dentre as quais podemos destacar: (1) a unidade de intervenção adotada não foi o lote, mas a quadra, implicando em demolições das edículas e supressão das divisas, de forma a transformar miolos de quadra em áreas de lazer e estacionamento, desconfigurando o parcelamento original e a implantação das construções no lote; (2) os procedimentos de recuperação e restauro não consideraram parâmetros aceitos internacionalmente, preferindo enfatizar critérios impostos pelas empresas patrocinadoras ou por empreiteiras, 
como em relação ao acabamento e cromatismo das fachadas, prejudicados pela utilização de argamassas e tintas de base acrílica; e (3), com a ausência de políticas sociais, a população de baixa renda que ocupava o casario foi desalojada sem o apoio de um programa de reinserção habitacional. Somente em etapas posteriores esses equívocos começaram a ser corrigidos.

A sustentabilidade do projeto também foi comprometida pela forma unilateral da intervenção, financiada e conduzida pelo governo estadual, que ficou responsável pela manutenção posterior dos espaços públicos e pelas fachadas das edificações recuperadas, que passaram a ser ocupadas por serviços voltados ao turismo e lazer, cedidas em sistema de aluguel ou comodato por preços bastante reduzidos, sem as respectivas contrapartidas de manutenção por parte dos ocupantes. A grande maioria da população residente foi remanejada e o acesso à área passou a ser direcionado para turistas e para a classe média, que aí podiam transitar sob forte aparato policial.

A política voltada à mercantilização do patrimônio cultural apresentou, desde cedo, sinais de fracasso: negócios voltados ao turismo foram fechados, ações de animação cultural incentivadas pelo governo diminuíram e a segurança foi retraída. Assim, iniciou-se um processo inverso, de progressiva retomada desse espaço pela população moradora do entorno - visível na instalação de bares e lojas voltadas à população de baixa renda.

Atualmente, decorridos 20 anos do início dessas intervenções, o Pelourinho mostra os sinais dessa insustentabilidade e da falência das políticas turístico-culturais ali implantadas. A maioria dos restaurantes de luxo, livrarias, lojas de moda, joalherias e ateliês de arte fecharam suas portas e cederam lugar a outros serviços de apoio ao morador das imediações, como bares, barbearias, comércio popular etc. Alguns pontos de influxo turístico ainda persistem, como aqueles situados nas imediações das igrejas de São Francisco e do Carmo, sobretudo após a transformação do mosteiro desse último em hotel de alto luxo de uma rede internacional. No restante da área do Pelourinho e do centro histórico como um todo, o local parece finalmente voltar a ser apropriado pela população baiana - os segmentos da classe média baixa, que residem nos bairros próximos.
Hoje, o governo estadual da Bahia parece direcionar suas atenções para outras localidades - a região do litoral sul baiano, destinada à exploração de um turismo de lazer exclusivo e sofisticado, e as praias do litoral norte, ao longo da Linha Verde, com resorts e grandes complexos hoteleiros voltados ao turismo de maior escala - cujos pacotes costumam incluir uma visita ao centro histórico, a qual, porém, pode ser substituída pelo mini-Pelourinho, simulacro assumido que orna um dos maiores complexos de resorts.

Assim, o Pelourinho volta, aos poucos, a buscar uma possível sustentabilidade, estabelecendo uma relação de melhor equilíbrio funcional com a cidade, abrigando agora uma população e classe consumidora muito mais consciente dos atributos históricos que o local possui. Apesar da ainda precária condição social desses potenciais ocupantes, acena-se para um futuro no qual o patrimônio edificado pode ser mantido e preservado - desde que o setor público incremente ações educativas e de monitoramento nas intervenções que esses usuários possam vir a realizar no patrimônio edificado; que é, sobretudo, patrimônio da humanidade.

\section{São Paulo}

\section{As fundações de São Paulo e \\ o papel da acrópole}

São Paulo nasceu sobre uma colina. Embora pouco reste hoje de sua fisionomia original, por trezentos anos a vila, depois cidade, criada no planalto de Piratininga a partir de 1554 desenvolveu-se sobre sítio elevado dominando os arredores, segundo padrão característico das fundações urbanas coloniais luso-brasileiras. Mais que isso: quando nos deparamos com o núcleo que a iconografia e a cartografia registram com clareza, pela primeira vez, na virada do século XVIII para o XIX, temos um exemplar marcante de ocupação em acrópole, reunindo muitos dos principais traços do urbanismo de colina de raiz portuguesa. Cidade de colina por excelência, poderia ser vista como compêndio de elementos e soluções do gênero, encontrados em nossa urbanização colonial.

Embora o papel estratégico da região dos campos de Piratininga - situada num dos entroncamentos 
do caminho indígena do Peabiru, que ligava o litoral às bacias dos rios Paraná e Paraguai, e daí ao altiplano andino - logo tenha sido identificado pelos colonizadores, a escolha por uma fundação em acrópole não foi imediata. A história de São Paulo - região "eminente e arrebatada", no dizer de Rocha Pita (PITA, 1976) - começa em 1530 com a expedição de Martim Afonso de Souza - comandante da armada com a qual Dom João III pretendia retomar o controle da costa brasileira e explorar o rio da Prata (DEUS, 1975). Naquele momento, o complexo estuarino de ilhas e manguezais, descoberto em 22 de janeiro de 1502, dia de São Vicente, era conhecido como Porto dos Escravos, onde portugueses traficavam com cativos indígenas. Mais ao sul, em Cananeia, outro grupo dedicava-se ao mesmo comércio. Ambos eram terminais da rede de caminhos conhecida como Peabiru, que ligava o litoral aos domínios incas (TEODORO; RUIZ, 2004).

Frustrada sua tentativa de subir o Prata, em 1532 Martim Afonso resolveu investir na ocupação da área de São Vicente, que lhe foi concedida como capitania hereditária (1534-1536). Limítrofe à linha de Tordesilhas, a região vicentina era ponto estratégico nas disputas entre castelhanos e portugueses. Ali seria preciso controlar não apenas a costa, mas os caminhos do planalto - seja como acesso às riquezas do altiplano, ou como ponto de partida para a escravização ou catequização das numerosas tribos indígenas do planalto.

Uma vez transposta a íngreme serra de Paranapiacaba, a região de Piratininga era livre de matas, tinha o clima temperado, e ali o piscoso Tamanduateí desaguava no Tietê - rio que esboçava caminho natural para o interior (PRADO Jr., 2012). Portugueses já lá havia; Martim Afonso aliou-se a esses pioneiros e organizou-os, junto com os recém-chegados, em duas vilas, uma no litoral, São Vicente, primeira sede da capitania, outra no planalto, Piratininga (LEITE, 1954).

Quanto ao sítio, nenhuma das escolhas foi feliz. 0 porto insuficientemente protegido de São Vicente foi logo superado pelo estuário de Santos, criado já em 1536 no outro extremo da mesma ilha litorânea, recebendo foral de vila em 1546. Piratininga desapareceu sem deixar vestígios, e não há consenso entre os historiadores a respeito de onde se situava.

Quando Tomé de Souza assumiu o Governo-Geral do Brasil em 1549, desenhou-se nova política para a colônia: o cultivo de cana-de-açúcar, já iniciado em São Vicente e Pernambuco, foi priorizado. Para tanto, a ocupação da costa seria completada e fortalecida, evitando-se incursões pelo interior (TEODORO; RUIZ, 2004). A colaboração dos jesuítas seria outro fundamento desse projeto - intermediando as relações com os indígenas, pacificando-os em aldeamentos e legitimando, pela catequese, o domínio português.

Como já havia feito Martim Afonso, Tomé de Souza proibiu aos portugueses de São Vicente subir ao planalto. Preocupava-se em manter fortalecidas as posições no litoral, evitando a criação de núcleos afastados, sem controle; em evitar o acesso indiscriminado a possíveis regiões auríferas, reservadas à Coroa; e em coibir o contato com os castelhanos.

Em 1552-1553, Nóbrega passou da Bahia a São Vicente, acompanhando a viagem de inspeção de Tomé de Sousa. Relatos sobre a docilidade dos tupiniquins, e especialmente dos guaranis - contrastando com os aguerridos tupinambás da Bahia - despertaram a ideia de concentrar o esforço dos jesuítas naquela região. Subindo a serra em fevereiro de 1553, o governador-geral expediu ordem aos mesmos de se reunir num povoado na Borda do Campo, junto à ermida existente de Santo André e sob o comando de João Ramalho. Em seguida, o núcleo recebeu foral de vila por parte do capitão-mor locotenente Antonio de Oliveira, em nome do donatário Martim Afonso.

Nóbrega já alimentava a ideia de levar o projeto jesuítico aos sertões do Sul, tendo escrito para o governador e para o provincial da Companhia de Jesus em Portugal, sem, contudo, obter autorização para criar uma casa inaciana no planalto. Seus conflitos em Salvador com o bispo Sardinha contribuíram para que permanecesse em São Vicente, de onde subiu a serra em agosto de 1553 para batizar 50 meninos índios. Percorreu o planalto por cerca de um mês, encontrando-se com João Ramalho e Tibiriçá. Confirmado em seus propósitos, escreveu em outubro ao próprio rei (BUENO, 2006). Recebeu então sua nomeação como provincial da Companhia de Jesus no Brasil (DEUS, 1975), e, fortalecido, decidiu consolidar por conta própria o núcleo de catequese no planalto pela criação de uma "casa de meninos". Para tanto, foi escolhido, em vez do povoado escravista de Santo André, outro sítio, próximo à povoação de Piratininga, onde se concentravam os tupiniquins mais amigáveis, da tribo de Tibiriçá. 
Tratava-se de uma colina entre o Tamanduateí e seu afluente Anhangabaú, que contava com várias vantagens: tinha significado religioso para os índios; dispunha de fontes de água potável; era ponto dominante na paisagem, facilmente defensável, e estava ao lado do trecho mais piscoso do rio Tamanduateí ou Piratininga ("peixe seco" em tupi), fonte crucial de alimento. Para ali, foi enviado grupo de religiosos, sob o comando do padre Manuel de Paiva; e ali, segundo Anchieta, se celebrou a primeira missa no dia da conversão de São Paulo - apóstolo dos gentios - a 25 de janeiro de 1554.

Sobre o terreno elevado de formato triangular, foi escolhido para situar o colégio um ponto a cavaleiro do rio, protegido por encosta íngreme com 25 metros de altura, mas com acesso próximo a esse importante meio de transporte e abastecimento. Nesse sentido, era análogo ao sítio escolhido por Tomé de Sousa em Salvador quatro anos antes, à beira da falésia sobre a baía.

Nóbrega, que permaneceria vários anos em São Paulo, justificou, em carta de 1554 ao rei Dom João III, sua decisão, afirmando que o sítio escolhido seria "a porta e o caminho mais curto e mais seguro para entrar nas gerações do sertão" (NÓBREGA, 1554 apud NÓBREGA, 1988, p. 144) As tribos que ocupavam o planalto, até o Paraguai, eram mais dóceis e acessíveis à catequese. Tal projeto - que culminaria com a maciça presença dos jesuítas espanhóis entre os guaranis nos séculos seguintes - era acalentado pelo próprio superior da Companhia, Santo Inácio de Loyola (KEHL, 2005, p. 60-64).

Logo o acerto da escolha se impôs. Em face das disputas entre os mamelucos de Santo André e os inacianos, pelo controle dos índios, as qualidades do sítio serviram aos propósitos de Nóbrega. Em vez da vulnerável vila na planície, mais valia o núcleo jesuítico na colina de Inhapuambuçu ou "morro que se vê ao longe" (KEHL, 2005, p. 92). Assim, logo em 1558, São Paulo obteve status de vila. Quando o terceiro governador-geral, Mem de Sá, simpático aos jesuítas, esteve na região, em 1560, determinou aos moradores de Santo André que se transferissem para ali, levando com eles Câmara e pelouros, e que construíssem uma paliçada ou muro de taipa como defesa. Os vereadores andreenses assentiram e justificaram a mudança por ser a acrópole "lugar mais forte e mais defensável, e mais seguro assim dos contrários como dos nossos índios" (ACTAS DA CÂMARA
DE SANTO ANDRÉ DA BORDA DO CAMPO, 1561 apud PRADO, 2004, p. 102). Os índios de Tibiriçá já haviam se mudado para ponto próximo desse recinto, transferindo-se de sua aldeia original, situada no Guaré (atual Luz) para o local onde hoje se encontra o mosteiro de São Bento. A aldeia de Caiubi, antes no Geribatiba (atual Santo Amaro) foi transferida para área entre o Carmo e a Tabatinguera (PORTO, 1992). Em 1562, Tibiriçá e Caiubi ajudaram os colonos a repelir um ataque de tupiniquins rebelados, após o que a vila se consolidou.

Mudanças similares, abandonando-se as fundações urbanas iniciais por outras em acrópole, também ocorreram em Salvador (1549) e no Rio de Janeiro (1564). Sítios elevados próximos a portos ou cursos d'água combinavam proteção e acessibilidade, condições usualmente antagônicas. Nessa delicada equação, a máxima eficácia era obtida onde uma encosta abrupta domina uma baía ou rio navegável. A vida política e religiosa concentrava-se no topo, onde residiam os estratos dominantes - dando origem, na terminologia portuguesa, à "cidade alta"; a vida material, o comércio e a navegação ocupavam a "baixa" - elementos presentes em inúmeras cidades do mundo luso.

\section{4 a 1600: o núcleo primitivo}

São poucas as informações disponíveis sobre a configuração inicial da vila. A carência de cartografia e iconografia, e a precariedade dos registros escritos - algumas passagens das atas da Câmara não permitem reconstituições exatas. Sabe-se que o núcleo se estabeleceu em torno do colégio dos inacianos e sua igreja, à qual se adicionou a matriz, futura Sé, no exíguo trecho protegido pelo primeiro muro. Entre 1580 e 1600, o muro foi reparado e um segundo trecho foi murado, ampliando-se um pouco o território urbano (TAUNAY, 2003). No século seguinte, pacificadas as tribos próximas, a cidade passou a se expandir sobre toda a colina.

Um dos mais importantes esforços de reconstituição da São Paulo quinhentista foi empreendido por Nestor Goulart Reis em São Paulo: Vila, cidade, metrópole (2004). Sua hipótese para o traçado dos muros de taipa, apoiada em estudos anteriores de Teodoro Sampaio e Nuto Sant'Ana, é a de que o núcleo protegido não superaria oito hectares, e 
corresponderia à área entre o Pátio do Colégio e a matriz (iniciada em 1598), chegando apenas à altura do início da futura rua do Rosário (atual XV de Novembro) (REIS, 2004). Por volta de 1580, o muro foi ampliado, chegando à altura do futuro Largo da Misericórdia, onde, provavelmente, ficava uma das portas. Outra poderia estar na saída do caminho do Guaré, futura Rua do Rosário, via de comunicação com a aldeia de Tibiriçá. Porta importante conduzia ao litoral, trajeto consolidado pelo padre Anchieta a partir de 1560.

As três portas correspondiam aos três principais acessos, orientados rumo aos vértices da acrópole triangular. Ao norte, havia o citado caminho do Guaré, que levava aos campos do Guaré (atual Luz) e ao ponto de travessia do rio Tietê (Ponte Grande). Também conduzia, por meio de uma derivação, a ladeira do Porto Geral, ao porto de comunicação fluvial e abastecimento de gêneros, à beira do Tamanduateí. A oeste, um caminho na diretriz da futura Rua do Ouvidor (hoje José Bonifácio) conduzia ao ponto de travessia do Ribeirão Anhangabaú e à estrada para o aldeamento de Pinheiros. Esse percurso contava com uma variante, na diretriz da atual Rua Direita, descendo até o mesmo ponto pela ladeira de Santo Antonio (atual Doutor Falcão). 0 trajeto para o litoral passava pela diretriz da futura Rua do Carmo (hoje Roberto Simonsen) até a ladeira da Tabatinguera, que conduzia ao ponto de travessia do Tamanduateí e, acompanhando a várzea, chegava ao topo da serra. Mais tarde uma variante, seguindo pela atual Liberdade até o Lavapés, se tornaria a mais percorrida no rumo sul (REIS, 2004).

A subida para a vila impunha uma escolha peculiar, recorrente no urbanismo de encostas de matriz lusa: como resolver a transposição de altura? Duas alternativas se colocavam: poderiam ser criadas ladeiras diagonais às curvas de nível, mais longas e com menor declividade, ou poderiam ser abertas ladeiras transversais às curvas de nível, mais curtas e íngremes. De início simples trilhas, vários dos primeiros acessos abertos em São Paulo adotaram a primeira opção, dando origem às ladeiras da Tabatinguera, do Porto Geral e de Santo Antonio. Alguns cruzaram as curvas de nível mais perpendicularmente, como a ladeira do Ouvidor e o Beco do Colégio.

As ladeiras menos acentuadas corresponderiam a uma declividade máxima de até $10 \%$ ou $12 \%$, manejável por carroças ou carros de boi. As ladeiras perpendiculares, por sua vez, podiam significar um aclive máximo de até $20 \%$ ou pouco mais; seriam transitáveis apenas a pé ou a cavalo, e, até o surgimento das tropas de mulas no final do século XVIII, não permitiriam o transporte de cargas.

A implantação da vila em acrópole reproduzia, de certa maneira, a situação do território dos Campos de Piratininga no planalto, e acentuava o percurso de elevação espiritual coroado pela escola dos jesuítas. No relato de Fernão Cardim e nos depoimentos dos padres Baltasar Fernandes (1565) e Anchieta (1585) (TAUNAY, 1954), São Paulo surge como utopia bucólica de clima agradável e frutos abundantes: "esta terra parece um novo Portugal" (CARDIM, 1980, p. 174).

Tudo indica que a vida urbana era fortemente ruralizada nos primeiros tempos. As áreas para quintal solicitadas repetidas vezes pelos moradores à Câmara serviam sem dúvida para hortas, pomares, criações e até currais. Sobre a colina ou em sítios ao redor, esses usos marcavam uma paisagem campestre entremeada por um quadro construído ainda modesto, precário e descontínuo, animado apenas pelas festas religiosas. Nessas ocasiões era preciso tirar o mato das vias públicas, roçar e capinar as testadas (PORTO, 1992). Atividades artesanais ou mercantis eram mínimas; para a sobrevivência era essencial a posse de terras e de escravos indígenas para cultivá-las. Com o tempo, foi preciso entrar cada vez mais pelo sertão em busca de novas presas, montando-se, para tanto, ambiciosas expedições denominadas bandeiras. 0 trabalho escravo e o sistema das sesmarias permitiram o florescimento de grandes propriedades rurais no entorno da vila.

Devido à carência de pedra e de madeiras de lei, as construções eram todas de taipa, principalmente taipa de pilão, usando-se a taipa de mão para paredes internas e obras menos importantes. Inicialmente cobertas de sapé, passaram a ser cobertas com telhas a partir do final do século XVI. Também os muros foram feitos de taipa. Isso significava que as construções estavam sujeitas ao desgaste e arruinamento se fossem expostas às águas pluviais. Fazia-se necessário protegê-las com largos beirais, e evitar ao máximo as enxurradas. Nestor Goulart assinalou a importância desse fator na configuração urbana inicial; a necessidade de desviar as águas da chuva, por meio de valas ou regos, ao largo das casas. Teriam sido criadas duas valas, desembocando na encosta pelos lados da área murada: o 
"buracão do Carmo" em frente à igreja e convento do mesmo nome; do outro lado a vala atravessava a "horta dos padres", ou seja, os terrenos plantados da encosta pertencentes ao colégio dos jesuítas (REIS, 2004, p. 21-22).

1600 a 1711: primeiros padrões urbanísticos, perfil da ocupação e marcos construídos

Meio século após a fundação, a ocupação ultrapassou o núcleo murado entre as valas, espraiando-se por sobre o restante do topo da colina. Na virada do século XVI para o XVII, estabeleceram-se, fora do perímetro delimitado inicialmente, as três grandes ordens religiosas, escolhendo para isso pontos estratégicos nos vértices da acrópole triangular: carmelitas (1592), beneditinos (1598) e franciscanos (1640-1644).

A localização dos conventos reproduzia a situação privilegiada do colégio jesuítico. Os religiosos contavam com terrenos amplos, a cavaleiro das encostas, facilmente defensáveis, ao lado das principais vias de comunicação que levavam à vila, dispondo ainda de generosas áreas para pomares e hortas, e acesso direto aos cursos d'água no sopé da colina. Além disso, a opção pelos vértices respeita determinação papal de Júlio II, de 1509, estipulando que as ordens religiosas deveriam se instalar a pelo menos 140 vergas (aproximadamente $520 \mathrm{~m}$ ) umas das outras. Exceção era feita apenas aos jesuítas, desde o pontificado de Pio IV (1559-1564) (LEMOS, 2004a).

Em comparação com Salvador e Rio de Janeiro, a iconografia colonial paulistana é extremamente escassa. Para um período de mais de duzentos anos, dispomos apenas de um ou outro desenho parcial e esquemático, servindo para representar a vila em mapas da região: destacado por Taunay, o borrón de D. Luís de Cespedes Xeria, no qual o núcleo urbano é representado pelo esboço sumário de um único edifício, provavelmente a Casa de Câmara, com uma grande cruz ao lado (TAUNAY, 1954, p. 25, 32); os interessantíssimos desenhos encontrados por Jaime Cortesão na Real Academia de la Historia em Madri - um dos quais publicado pela Imprensa Oficial do Estado em 2000, citado por Aziz Ab'Saber (AB'SABER, 2004) - e atribuídos por Nestor Goulart Reis a Alessandro Massaï, engenheiro italiano que esteve no Brasil ao tempo do governador Dom Francisco de Sousa (primeira década do século XVII); e o pequeno, mas expressivo, desenho constante do Atlas de João Teixeira Albernaz (1631), baseado em observação realizada por seu pai Luís Teixeira no final do século XVI, a partir da várzea do Tamanduateí, no qual podemos identificar a implantação em acrópole, os muros da vila e duas igrejas, provavelmente as do colégio e do Carmo (REIS, 2004).

Nos desenhos atribuídos a Massaï, a vila é representada ao término do Caminho do Mar, após a travessia dos rios e das pontes sobre o Tamanduateí, onde surge um conjunto de seus principais edifícios, esmiuçando detalhes e curiosidades. Deixam clara a disposição triangular da ocupação urbana, entre dois cursos d'água, destacando dezesseis corpos de construção; a cruz mencionada por Cardim; a igreja do Carmo; a igreja jesuítica, coroada por torre, e seu colégio - com espaço murado e plantado ao fundo, chegando ao rio; depois, São Bento, ainda pequena ermida; as igrejas da Misericórdia e de Santo Antonio, ambas muito simples; a matriz, futura Sé, ainda sem torre; finalmente, aglomerado de construções de diferentes alturas, ladeadas por curral repleto de bovinos. Currais similares surgem fora da vila, cercados por altos muros (REIS, 2004).

A visão do desenhista, mostrando construções soltas sobre a colina, exprime o caráter do núcleo inicial, carente de arruamento regular. Em torno do colégio e da matriz, casario e igrejas eram entremeados por espaços livres irregulares, nos quais os animais perambulavam e o mato crescia. As trilhas que sulcavam o terreno precisavam ser roçadas antes das procissões, que não apenas constituíam o uso mais importante do espaço público, como geraram algumas das principais diretrizes viárias: o surgimento de denominações importantes como Carmo, São Bento e Santo Antonio exigiu o estabelecimento de vias regulares para os trajetos religiosos.

\footnotetext{
2 As atas da Câmara, excepcionalmente preservadas desde o século XVI, e outros documentos interessantes, publicados por iniciativa do prefeito Washington Luís (1914-1918), e posteriormente pela Revista do Arquivo Municipal, forneceram material para as abordagens do século XX: como Vida e morte do bandeirante, de Alcântara Machado (São Paulo, Revista dos Tribunais, 1928), a vasta obra de Affonso de Taunay, os estudos de Paulo Prado (Paulística etc. São Paulo: Companhia das Letras, 2004), Sergio Milliet e Sergio Buarque de Holanda.
}

urbe. Revista Brasileira de Gestão Urbana (Brazilian Journal of Urban Management), v. 5, n. 1, p. 47-69, jan./jun. 2013 
Na virada do século XVII, ao tempo da União Ibérica, começam a surgir nas atas da Câmara ${ }^{2}$ referências a arruamentos e a ordenamentos urbanísticos. Em 1594, esta proíbe deitarem-se alicerces ou levantarem-se construções sem sua permissão (TAUNAY, 1954). De início, tais preocupações coincidem com o governo de D. Francisco de Sousa, governador-geral do Brasil (1591 a 1602) e governador da repartição do Sul (1609 a 1611), que interessou-se por São Paulo por conta da incipiente mineração, instalando-se na vila em 1599 (LEITE, 1954).

Teria imposto padrões urbanísticos mínimos, incrementando a construção e regularizando o arruamento. Fazia parte da sua comitiva engenheiro militar italiano formado em Lisboa, Baccio da Filicaia, além do citado Massaï. Substituído no governo da colônia, envolveu-se com as primeiras grandes bandeiras, das quais foi financiador. Filipe II de Portugal (III de Espanha) fez-lhe Marquês das Minas e governador do Sul, mas D. Francisco faleceu pouco tempo depois em São Paulo, em 1611, sendo brevemente sucedido por seu filho D. Luís de Sousa, até 1612. Este, segundo ata da Câmara de julho daquele ano, havia determinado que fossem mantidas as diretrizes de arruamento estabelecidas anteriormente, presumivelmente no governo de seu pai, por "oficiais passados" (REIS, 2004, p. 40-41) que poderiam ser tanto os oficiais camaristas como os engenheiros militares a serviço de D. Francisco. De qualquer maneira, essas diretrizes seriam reiteradas e fortalecidas ao longo do século XVII. Há notícia da contratação de um técnico, provavelmente ex-piloto de navio, como arruador pela municipalidade em 1636: Pêro Ruiz Guerreiro, "homem de mar que entendia do rumo de agulha", para que "fizesse nesta vila o ofício de arrumador de todas as terras, por ser ofício necessário ao bem comum deste povo" (TAUNAY, 1954, p. 88). Em 1638, as atas da Câmara já citam a abertura de uma rua reta, conforme transcreve M. Marx: "foi tomada uma rua nesta vila de São Paulo para nobreza dela [...] correrá a rua direita às casas [...] para aquela parte indo a rua direto" (ATAS DA CÂMARA MUNICIPAL DE SÃO PAULO, 1638 apud MARX, 1989, p. 133).
Assim, a partir do núcleo irregular inicial, surgiu uma série de ruas retas, algumas estritamente paralelas ou perpendiculares, traçadas por profissionais habilitados, sem, contudo, formar uma quadrícula. É importante frisar que a afirmação desse arruamento exigia esforço constante no sentido de disciplinar a ocupação, impor alinhamentos, fazendo recuar ou avançar construções, fiscalizar testadas, aberturas, beirais, e enquadrar, ao longo do tempo, um processo de urbanização muitas vezes casuístico (SILVA, 1984). Em 1640, proibiu-se edificação sem arruamento prévio; em 1642, desapropriaram-se casas que comprometiam o espaço central da vila; em 1687, determinou-se que demarcações de datas e alinhamentos se fariam na presença do ouvidor ${ }^{3}$.

0 traçado somente será documentado mais de um século mais tarde, em levantamento encomendado pelo governo do Morgado de Mateus (17651774). Como este mostra uma ocupação já consolidada, e foi realizado ao final de um longo período de decadência, podemos supor que parte substancial do arruamento date ainda do século XVII, até mesmo anterior aos célebres conflitos entre os Pires e os Camargo, que comprometeram a autoridade municipal entre 1640 e 1660.

A sudeste surgiu a futura Rua das Flores (atual Silveira Martins), paralela à Rua do Carmo criada sobre o principal acesso à vila; a sudoeste, as ruas que se chamariam de São Gonçalo (hoje lateral da Praça da Sé), da Esperança e do Quartel (atual Onze de Agosto); a oeste, a partir da Misericórdia, a rua Direita para Santo Antonio adotou traçado retilíneo, e a rua criada entre São Bento e São Francisco, outra importante via processional, seguiu diretriz perpendicular àquela, gerando um cruzamento em ângulo reto: os "quatro cantos". Além desses traçados regulares, consolidaram-se ruas sobre caminhos existentes: a via rumo ao caminho de Pinheiros, tornou-se Rua do Governador (depois do Ouvidor, atual José Bonifácio); o trecho inicial do caminho do Guaré tornou-se Rua do Rosário (atual XV de Novembro); ruas menos importantes foram as da Cruz Preta (atual Quintino Bocaiúva), do Jogo da Bola (atual Senador Feijó) e do Comércio (atual Álvares Penteado); havia ainda travessas, becos e azinhagas.

\footnotetext{
3 Uma abordagem de tom histórico-sociológico desse tema encontra-se no já clássico São Paulo 1554-1880: Discurso ideológico e organização espacial, de J. T. da Silva (São Paulo: Moderna, 1984), que analisou as intervenções da Câmara sobre a configuração do espaço urbano, dos arruadores seiscentistas aos engenheiros do século XIX.
} 
Quais eram os padrões seguidos nesse arruamento? Conforme verificamos nos primeiros levantamentos em escala, já no século XIX, as ruas retas adotavam a largura de 40 palmos (8,8 metros) - uma das larguras padrão vigentes em Portugal, adotada para as ruas menos importantes da Baixa pombalina no projeto de 1758 (SANTOS, 1999) e no bairro das Águas Livres projetado por Carlos Mardel em 1759 (ROSSA, 1998). 0 mesmo padrão consta do termo de demarcação da vila de Montemor-o-Novo criada no Ceará (1764) (SANTOS, 2001).

Contudo, é possível que esse padrão tenha sido imposto de maneira parcial e gradual em São Paulo, talvez apenas a partir do século XVIII, sobre traçados já existentes, por meio da adaptação progressiva das construções. A regularidade de larguras e alinhamentos da Planta da Restauração parece ser mais desejo que realidade, sendo desmentida por levantamentos topográficos posteriores.

A dimensão de 40 palmos sobrevive hoje em trechos das ruas São Bento, José Bonifácio e Onze de Agosto. É inferior à das vias mais importantes da Baixa, como as ruas Augusta, do Ouro e da Prata, que tinham 60 palmos ou 13,2 metros - largura também imposta em Salvador, já por volta de 1700, por exigência da Câmara (REIS, 2000). Cem anos depois seria adotada em São Paulo, na Cidade Nova, e consagrada em normativas do século XIX como o Código de Posturas de 1875. Mas é bem superior àquela usada em projetos portugueses do século XVI, como o Bairro Alto de Lisboa, onde as vias principais têm seção de 24 palmos, e as travessas 20 palmos (CARITA, 1999).

Essa última medida $(4,4$ metros) foi referência para travessas e becos paulistanos: seus últimos remanescentes, o Beco do Colégio e a Rua do Comércio (antigo Beco do Inferno), mantêm até hoje largura semelhante. A despeito do nome, não eram becos sem saída e sim travessas entre ruas ou acessos a espaços livres. Muitos foram alargados posteriormente ou desapareceram.

Quanto à largura das testadas, o padrão luso tendia a reproduzir um parcelamento com lotes de 25 ou 30 palmos de largura (5,5 ou 6,6 metros). Ambas as medidas são correntes no Bairro Alto, arruado nas primeiras décadas do século XVI. No caso paulistano, para as casas mais ricas, havia também lotes em dobro, ou seja, 50 ou 60 palmos (11 ou 13,2 metros); Taunay menciona terreno de seis braças (60 palmos) na Rua Direita em 1656 (TAUNAY, 1954).

A paisagem urbana era dominada, em termos visuais, espaciais e funcionais, pelos edifícios religiosos. Conforme o uso português, as principais vias nasciam, desembocavam ou confluíam em largos marcados por templos: Colégio, matriz (depois Sé), Carmo, Misericórdia, São Francisco, São Bento, Rosário. Tais alargamentos irregulares do espaço público serviam às cerimônias religiosas, aos encontros e ao comércio. Como a vila não tinha ainda maior expressão política, não havia praças como a que marcava, em Salvador, o lócus do poder colonial. Mesmo assim a posição estratégica de São Paulo, o sucesso das bandeiras e a decadência de São Vicente levaram à transferência da sede da capitania para o planalto provisoriamente, em 1682; definitivamente, em 1709, a vila foi elevada a cidade em $1711^{4}$.

\section{1 a 1808: consolidação da ocupação em acrópole}

Embora as atas da Câmara deem notícia de ruas, becos, igrejas, cessões de terrenos, usos e costumes urbanos, suas descrições são muito imprecisas. Apenas na segunda metade do século XVIII, foi realizado o primeiro levantamento da cidade, ao que tudo indica, na gestão do Morgado de Mateus (1765-1774), que deu origem a uma planta que pode ser conhecida por meio de cópia pouco posterior, hoje no Arquivo Histórico Militar do Rio de Janeiro, redescoberta e publicada recentemente por Nestor Goulart Reis (REIS, 2004).

A chamada Planta da Restauração, coincidindo com a restauração da Capitania de São Paulo em 1765 , revela a ocupação urbana existente no terceiro

\footnotetext{
4 Elementos para a análise da formação e das transformações da sociedade paulistana nos períodos colonial e imperial, embora não estejam no escopo da presente pesquisa, concentrada em aspectos histórico-morfológicos, podem ser encontrados em obras diversas, de estudos clássicos a recentes. A história da capitania e da província de São Vicente/São Paulo mereceu a atenção de estudiosos desde o século XVIII, com os alentados esforços de Frei Gaspar e Pedro Taques. No século seguinte, o Quadro Estatístico de Daniel Pedro Muller, o Quadro Histórico da Província de São Paulo, de Machado de Oliveira, A Província de São Paulo, de Joaquim Floriano de Godoy, e a obra de Azevedo Marques, compilaram exaustivamente o material então disponível.
} 
quartel do século XVIII. Além das ruas já citadas, destaca-se a Rua da Boa Vista, aberta em cotovelo, provavelmente no início do século, em trecho da acrópole adjacente à encosta do Tamanduateí. Seu nome sugere uma valorização dos terrenos situados a cavaleiro da encosta, que dispunham de vista sobre a várzea, e reproduz a denominação de rua de Lisboa, dominando o Tejo. Também se destaca a abertura da Praça Municipal, a primeira praça regular da cidade, de forma trapezoidal e dimensões amplas (aproximadamente 300 por $300 / 400$ palmos), onde se construiu a nova Casa de Câmara e Cadeia.

Mesmo assim, verificamos postura introvertida, já que as casas ocupavam todo o alinhamento dos lotes e voltavam suas frentes para o interior. Largos, pátios e praças eram pensados, preferencialmente, como espaços fechados, delimitados pelo casario e focados nos edifícios religiosos. Ruas e travessas surgiam entre um correr de casas o mais contínuo possível. As encostas permaneciam livres, e as ladeiras apresentavam poucas construções.

O território urbanizado alternava áreas de traçado mais ou menos regular. 0 núcleo original entre colégio e matriz apresentava ocupação menos regular, com corpos de construção desencontrados, sem paralelismo. Organizava-se em torno dos dois principais espaços públicos da cidade, o Pátio do Colégio e o Largo da Sé (a matriz fora reconstruída como Sé com a criação do bispado em 1748). Esse núcleo estendeu-se por meio de prolongamento não retilíneo na direção norte, acompanhando o antigo caminho do Guaré, com vias como as ruas do Rosário, do Comércio e Boa Vista. Ao sul, o trecho mais alto e plano da colina foi ocupado de forma mais regular, com dois conjuntos de ruas paralelas, Carmo/ Flores, desembocando na Tabatinguera; e São Gonçalo/Esperança/Quartel, desembocando na Praça Municipal. A oeste, o conjunto das perpendiculares ruas Direita e de São Bento organizava importantes eixos processionais, com quarteirões longos e retilíneos. Uma série de ruas convergia obliquamente para a descida do Piques e o Largo de São Francisco: do Ouvidor, do Jogo da Bola (atual Benjamin Constant) e das Freiras (atual Senador Feijó), cortadas pela Rua da Cruz Preta (atual Quintino Bocaiúva).

Toda a ocupação encontrava-se ancorada pelos edifícios religiosos. Conventos e igrejas do Carmo,
São Bento e São Francisco dominavam os vértices da colina; cada um contava com um espaço aberto à frente, largo, adro ou pátio, e com amplos terrenos adjacentes, descendo a encosta. Ao contrário dos principais espaços públicos, como o Pátio do Colégio, o Largo da Sé e a Praça Municipal - totalmente encerrados entre construções -, esses largos eram parcialmente abertos à paisagem; mas as frentes dos templos e conventos eram voltadas para o interior da aglomeração.

Após o mandato do Morgado de Mateus, uma série de outros governantes esclarecidos presidiu à ampliação da área urbanizada, e a algumas intervenções marcantes. A capitania entrava em novo período de prosperidade graças à cana-de-açúcar e ao comércio de tropas. Era preciso melhorar as vias de transporte e aparelhar os centros urbanos. Assim, nos últimos anos do século XVIII, calçou-se o Caminho do Mar, obra de Bernardo José de Lorena; construiu-se o quartel; abriu-se a Rua Nova de São José, atual Líbero Badaró; criaram-se chafarizes e calçaram-se as ruas. No início do século XIX, foi criada ligação direta na encosta do Tamanduateí, conduzindo à estrada que levava ao Vale do Paraíba e ao Rio de Janeiro. Para tanto, o governador Franca e Horta aterrou e pavimentou, por volta de 1804, o "buracão do Carmo", vala em frente ao convento do mesmo nome, abrindo a Ladeira do Carmo, via perpendicular às curvas de nível - adequada apenas às tropas de mula, que já protagonizavam o transporte de cargas.

Nos mesmos anos (1800-1822) começou a ser ocupada a Cidade Nova sobre a colina situada na margem oposta do Anhangabaú. Ali, o padrão de arruamento adotado foi o de 60 palmos $(13,20$ metros) de largura, equivalentes às ruas principais da Baixa pombalina; esse padrão perduraria ao longo do século, sendo consagrado pela Câmara no Código de Posturas de 1875, até ser suplantado, em 1886, pelo padrão de 16 metros, já sob o sistema métrico de medidas (implantado em 1874). Ligando a cidade existente à nova, foi construída a Ponte do Acu, contando com duas êxedras semicirculares lançadas sobre o vale e equipadas com bancos e parapeitos de pedra. Era a primeira intervenção urbana que explorava o potencial paisagístico do sítio paulistano.

Outras pontes também definiam os acessos à cidade: do Lorena, no Piques; do Carmo; e do Miguel 
Carlos, na continuação do caminho do Guaré (atual Rua Florêncio de Abreu) sobre o Anhangabaú. Eram pontos de controle de entrada e saída de pessoas e de mercadorias, sobre as quais se cobravam direitos e taxas variadas. Intervenções urbanísticas em São Paulo na virada do século XIX tinham assim o propósito de enquadrar a cidade nas diretrizes da Coroa.

\section{8 a 1850: Acrópole introvertida}

Não por acaso, começavam a se multiplicar levantamentos censitários e estatísticos, e também levantamentos do território, mapas da capitania e plantas da cidade. De 1810 a 1868, são muitos os levantamentos e poucas, relativamente, as mudanças na ocupação urbana. Contamos com as plantas de 1810, sua reelaboração em 1841, as do engenheiro Bresser (1841 e 1842), a de Carlos Rath (1855), e a de 1868. Na planta completa seguinte, de 1881, (já que a de Jules Martin, de 1877, é apenas parcial) a cidade já é substancialmente outra.

Como resumir o abundante material sobre a São Paulo da primeira metade do século XIX, quando a colina histórica reinava ainda quase inconteste, e os padrões coloniais haviam se consolidado de forma tão característica? Documento importante, embora fonte secundária, é a maquete da cidade circa 1840, encomendada por Affonso d'Escragnolle Taunay, diretor do Museu Paulista, em 1920, com vistas ao centenário da Independência, e realizada pelo modelador holandês Hendrik Bakkenist. Segue exposta no museu. Originalmente monocromática, em termos topográficos, volumétricos e arquitetônicos, ainda representa reconstituição fiel, na medida do possível, aos documentos originais consultados por Taunay (TAUNAY, 1937). Embora não possa reproduzir exatamente a situação de 1840, já que a documentação não cobre todos os detalhes nem corresponde a um único momento no tempo, obtém efeito geral bastante eficaz, apresentando elementos de forma elucidativa. A despeito do tratamento arquitetônico esquemático, e da ausência da vegetação, podemos apreciar a disposição e densidade do casario, a dimensão e conformação dos espaços livres, e a volumetria destacada das igrejas, conventos, edifícios públicos e alguns sobrados.
Com base nas plantas cadastrais do engenheiro Bresser, de 1841 e 1842, na iconografia disponível e na reconstituição em três dimensões de Taunay e Bakkenist, podemos tentar inferir algumas das características morfológicas da ocupação original em colina que marcou decisivamente a cidade de São Paulo até meados do século XIX. Após quase trezentos anos de consolidação, os padrões urbanísticos desenvolvidos lentamente atingem aí sua expressão mais acabada. Cidade luso-brasileira em acrópole por excelência, a São Paulo de 1840 se apresenta como um compêndio das formas e soluções adotadas nesse tipo de urbanização.

Em primeiro lugar, verificamos a presença do arruamento concentrado no topo da colina, composto por ruas de pouca declividade, quase planas. Tal ocupação tende a se limitar ao altiplano, interrompendo-se na borda da encosta. Apenas onde esta é menos íngreme, na descida para o Anhangabaú, encontramos uma exceção: a Rua Nova de São José, atual Líbero Badaró, aberta tardiamente, mas menos valorizada, servindo de fundos para a Rua de São Bento.

A transposição de nível é realizada por meio de número limitado de ladeiras, associadas às pontes que permitiam a travessia dos cursos d'água: Tabatinguera, Carmo, Constituição, Rua de São João/Ponte do Acu e o conjunto das ladeiras de Santo Antonio, Ouvidor e São Francisco, convergindo na ponte do Lorena. Becos menos importantes conduzem à margem do Tamanduateí: Porto Geral, Colégio e duas passagens atrás do Carmo. Tratavase de uma cidade isolada no alto, protegida atrás de rio e ribeirão, claramente delimitada, com poucos acessos, facilmente controláveis.

As ladeiras apresentavam declividade considerável, mas quase todas podem ser classificadas em dois tipos: diagonais às curvas de nível, ou seja, com declividade média entre 10 e $12 \%$, e, portanto, negociáveis para a maioria das carroças e carros de boi; e perpendiculares às curvas de nível, ou seja, com declividade superior a $15 \%$, acessíveis apenas a pedestres, cavaleiros ou tropas de mulas. As primeiras incluem as da Tabatinguera, Porto Geral, de Santo Antonio e a Rua da Constituição; entre as segundas, as ladeiras do Carmo, do Ouvidor e de São Francisco, e o trecho inicial da Rua de São João, um pouco menos íngreme. 0 Beco do Colégio alcança inclinação mais acentuada, atingindo quase $25 \%$, exigindo o emprego de degraus combinados à rampa. 
Não há diferenciação nítida entre ruas que acompanham as cumeeiras e as demais. Não obstante, podemos observar que a linha divisória das águas no topo da colina é acompanhada, a grosso modo, pelas ruas do Comércio (atual Álvares Penteado) e da Cruz Preta (atual Quintino Bocaiúva), encontrando-se no Largo da Misericórdia. Não eram ruas importantes, mas podem ter sido abertas para acompanhar a cumeada, medida crucial no urbanismo luso-brasileiro em termos da divisão e disposição dos lotes, e do carreamento das águas pluviais. Ao norte, essa linha descia até São Bento; ao sul, seguia subindo, passava pela Casa de Câmara e Cadeia e culminava no Morro da Forca.

Esse arranjo da cumeeira ficava escondido no terreno pouco acidentado do altiplano, onde o casario se avolumava. Esse núcleo já se tornara compacto, e seu traçado resultava da combinação entre ruas mais ou menos retas. Conjuntos de ruas retilíneas haviam sido lançados por técnicos especializados desde o século XVII, formando pequenos grupos de vias paralelas, perpendiculares ou convergentes, mas nunca chegando a uma quadrícula regular.

Esses conjuntos imbricavam-se com ruas e trechos menos regulares, muitas vezes derivados do núcleo quinhentista e de seus caminhos de acesso, como as regiões do Colégio, da Sé e da Misericórdia, as ruas do Rosário e da Tabatinguera. Algumas vias avançaram aproveitando as bordas da encosta, como as da Boa Vista e da Casa Santa.

A irregularidade não se refere necessariamente a eixos não retilíneos, mas também à variação das larguras nos diferentes trechos da via. Em termos da declividade, são poucas as inflexões. Apenas quando a rua se torna uma ladeira - Ouvidor, São João, Tabatinguera -, temos a mudança de um padrão próximo do plano para um grau de inclinação pertencente a outra categoria, podendo esta se mostrar mais ou menos acentuada, por ser perpendicular ou diagonal às curvas de nível.
0 arruamento se organiza em torno de pontos de articulação viária, com profusão de entroncamentos. As ruas paulistanas tendiam a convergir, situação favorecida pelo formato triangular da acrópole, e pela evolução urbana, na qual caminhos e ruas surgiam demandando pontos de interesse. Podemos citar, no núcleo quinhentista, os espaços fundadores: Largo do Palácio (antes, e hoje novamente, Pátio do Colégio) e Largo da Sé; na extensão seiscentista, os largos da Misericórdia e do Rosário, além dos Quatro Cantos; nos vértices da colina, os largos do Carmo, de São Bento e de São Francisco; no quadrante Sul, a Praça Municipal, os largos da Forca e da Pólvora; nos pontos de travessia do Anhangabaú, a Ponte do Acu e o Piques, rumo à Cidade Nova; nesta, o Zuniga (atual Paissandu), o Campo dos Curros (atual República) e a esplanada em frente à Luz (atual avenida Tiradentes).

Entroncamentos, largos e praças acompanhavam os edifícios mais importantes: palácio do governo provincial (antigo colégio dos jesuítas); igrejas, conventos (o de São Francisco transformado em Academia de Direito); Assembleia Provincial (antiga Casa de Câmara), Casa da Pólvora. Encaixados nos quarteirões, encontramos apenas o Convento de Santa Teresa, o quartel e a Igreja de Santo Antonio. Poucos edifícios particulares de relevo: alguns sobrados de potentados como a Marquesa de Santos, o Barão de Itapetininga, o Barão de Iguape e o Brigadeiro Luiz Antonio, sinalizavam uma topografia social essencialmente desigual ${ }^{5}$.

Fontes iconográficas da primeira metade do século XIX mostram a encosta do Tamanduateí - tema de predileção dos artistas viajantes, sendo registrada em detalhe por Ender e Pallière, entre outros. Nelas a relação entre cidade e colina continua marcada pelos traços originais. A ocupação encarapita-se no topo, onde o casario preenche toda a borda da elevação, voltando suas frentes para o interior e seus fundos para a várzea. Estes incluíam generosas

\footnotetext{
5 São Paulo carece ainda de estudos sobre os setores sociais desfavorecidos; em contraste, a vida das elites encontra-se bastante bem documentada. Vale lembrar o volume Vida cotidiana em São Paulo no século XIX: Memórias, depoimentos, evocações, organizado por C. E. M. de Moura, que procura traçar um panorama abrangente da vida na São Paulo oitocentista a partir de textos pouco conhecidos e/ou de época, mas recorre a memorialistas de elite como a Maria Paes de Barros de No tempo de dantes, Francisco de Assis Vieira Bueno e Everardo Vallim Pereira de Souza; além do diário da Princesa Isabel em sua visita de 1884. A obra traz ainda itens da dramaturgia paulistana, menções às expedições científicas, como as de Alexandre Rodrigues Ferreira; Saint-Hilaire; Spix e Martius; e Langsdorff; e aos primeiros artistas e fotógrafos que retrataram a cidade, como Manuelzinho Dutra, Hercules Florence e Militão de Azevedo.
} 
"varandas" usadas cotidianamente como espaço de estar e refeições. Abaixo do nível da rua, vemos arrimos, porões ou andares de sustentação abrirem-se nos fundos para o vazio do vale. Partes da habitação que normalmente não deveriam ser vistas encontram-se aí totalmente expostas. Os muros descem até o rio, onde se buscava água, se lançavam dejetos e se lavava a roupa, e fecham-se no sopé, ao longo da margem, demarcando os terrenos e indicando os perigos associados à várzea - malfeitores ou intrusos.

O olhar dos viajantes parece transitar em sentido oposto ao dos moradores: buscando os espaços abertos, registrando os quintais, as várzeas, os vazios às quais a cidade dava teimosamente as costas. Também focavam o âmago da aglomeração, mas ali a busca do pitoresco muitas vezes punha em evidência costumes curiosos, vestimentas exóticas, aventuras de tropeiros e peripécias de escravos. Registros mais isentos, como as aquarelas de Ender e os quase fotográficos desenhos em câmera obscura de Burchell, revelam uma paisagem pouco animada, de casas encerradas e interiores quase vazios. Acrópole introvertida, a São Paulo colonial, persistindo até meados do oitocentos, surgia como cidadela bucólica, avessa a mudanças; mas resumindo, na ocupação urbana consolidada em três séculos, traços característicos da urbanização colonial luso-brasileira.

\section{Após 1850: transformações posteriores}

É difícil crer que seja o mesmo local hoje conhecido como Centro Velho, no coração da metrópole. Após 1850, teve início uma série de intervenções que, ganhando ímpeto crescente, modificaram irremediavelmente o primitivo sítio paulistano, substituindo sucessivamente as edificações, alargando ruas, alterando traçados, criando novos espaços livres e acessos. Cercada por viadutos e vias rápidas, sufocada pelos arranha-céus, a colina histórica de São Paulo, antes aspecto memorável da cidade, quase desapareceu sob novos padrões e escalas de urbanização.

Qualquer esforço de recuperação dos elementos topográficos, paisagísticos ou morfológicos originais da colina histórica paulistana passa pelo estudo da ocupação urbana tal como ela se apresentava até aquele momento. Para isso, adotamos como área de estudo a colina original; a região elevada triangular, com aproximadamente 60 ha, compreendida entre os vales dos rios Tamanduateí, a leste, e Anhangabaú, a oeste, confluindo ao norte; e limitada ao sul pelo trecho adjacente ao antigo Largo Municipal e pela descida da Tabatinguera. Além de acessos e pontes, elementos cruciais para a definição do núcleo.

Podemos dizer que a situação original, típica do urbanismo de colina de tradição luso-brasileira, perdurou até os anos 1850, quando a retificação do Rio Tamanduateí, a abertura da Rua 25 de Março e a construção do primeiro mercado municipal alterou radicalmente a configuração da encosta leste. E é ainda, em grande parte, a mesma cidade registrada pelo fotógrafo Militão de Azevedo em 1862. Sua reconstituição em escritos, na iconografia e na cartografia, acompanhou a célere desaparição dos traços que se pretendia evocar ${ }^{6}$. Pacata, ensimesmada, tradicionalista, avessa às mudanças, a acrópole em nada lembraria a metrópole dinâmica surgida a partir do final do século XIX, com suas famílias encasteladas e seus hábitos reclusos; a acrópole paulistana, tão visível ao longe para os viajantes, encerrava-se numa introversão que a presença dos estudantes de Direito apenas começava a sacudir. Essa introversão só seria quebrada pela obra emblemática do Viaduto do Chá em 1888 com a demolição do sobrado baronial que fechava o acesso à encosta oeste, ou seja, à área de expansão urbana e ao progresso.

Quando, na virada do século XIX para o XX, foi preciso criar um centro moderno, que presidisse o território urbano ampliado pela riqueza do café, ele foi implantado sobre a mesma colina, apagando-se nesse processo os traços coloniais existentes. 0 "Centro Velho" sobre a colina sofreu

\footnotetext{
${ }^{6}$ Desde os esforços de documentação do fotógrafo Militão de Azevedo em 1862 e 1884, do estudioso e fotógrafo Afonso de Freitas (1985) nos primeiros anos de 1900; das evocações de memorialistas do século XX, como Jorge Americano (1962a, b, c) e Paulo Cursino de Moura (1943), culminando no monumental levantamento de Ernani da Silva Bruno em sua História e tradições da cidade de São Paulo, em três volumes (1954), e na coleção de mapas do IV Centenário. Material essencial para esta pesquisa.
} 
a concorrênciacada vez maior do "Centro Novo" estabelecido na elevação que lhe faz face, do outro lado do Anhangabaú; apesar disso, esforços de ampliação e modernização do centro empreendidos ao longo do século XX mantiveram - a despeito das dificuldades topográficas, custosamente vencidas por viadutos e aterros - o foco de seus esquemas viários radioconcêntricos ou radiais-perimetrais sobre o núcleo primitivo. Com o abandono do centro histórico pelas camadas dominantes, após 1970, a acrópole original, a qual os velhos paulistanos chamavam simplesmente de "a cidade", deixou de figurar em primeiro plano no cotidiano e no imaginário da metrópole. Mais recentemente, com movimentos pela recuperação urbanística do centro, a região volta a ser objeto de debates ${ }^{7}$.

Essa insistência na transformação do núcleo central, reinventado inúmeras vezes nos últimos cento e poucos anos, apagou quase completamente as características da ocupação original de matriz luso-brasileira. Intervenções modernas de vários matizes, do urbanismo haussmaniano oitocentista às propostas sitteanas de 1910, passando pelo rodoviarismo exacerbado dos anos 1930 a 1960, e chegando às reformas modernistas que acompanharam a implantação do metrô e a pedestrianização do centro após 1970, alteraram profundamente seu traçado, morfologia e volumetria ${ }^{8}$.

Praticamente todas as edificações coloniais foram substituídas. Ruas foram alargadas, retificadas, niveladas; lotes foram remembrados, e quarteirões inteiros, suprimidos. Largos e pátios ganharam contornos irreconhecíveis; surgiram novas praças e parques, logo substituídos por outras reformas e espaços públicos. Igrejas, conventos, chafarizes, sobrados, casinhas desapareceram. Os prédios ecléticos que sucederam ao casario colonial caíram, por sua vez, em face de edifícios modernos, hoje já obsoletos; as mesmas ruas foram alargadas, os mesmos pontos redesenhados e reconstruídos diversas vezes ao longo do século. A própria situação topográfica, antes tão evidente, foi escondida: a colina foi cercada por viadutos, arrimos, aterros; os desníveis do terreno foram eclipsados pelos arranha-céus. Até mesmo o Pátio do Colégio, celebrado como local de fundação da cidade, abriga hoje uma réplica hipotética da igreja dos jesuítas e um edifício cuja fachada busca reproduzir uma parte do colégio setecentista - ambos construídos entre 1950 e 1978. Cercado por um estacionamento, o conjunto não corresponde à implantação original do largo.

Contudo, a encosta leste, sobre o Tamanduateí, foi preservada nesse ponto por terrenos públicos (a antiga horta dos jesuítas, depois jardim do palácio do governo, hoje sem uso definido); e por legislação especial que limitou as alturas para manter a vista desimpedida a partir do sítio da fundação da cidade - revelando, a despeito das ruas abertas na meia encosta, o desnível abrupto que definiu a escolha do sítio e o nascimento da São Paulo em acrópole. Outro resquício da feição colonial no centro histórico é o Beco do Colégio, viela que desce a encosta entre a Casa n. 1 - antigo Palácio Episcopal, e a casa da Marquesa de S. Tudo alterado e restaurado várias vezes ao longo do século XX; mas pelo menos aí temos remanescentes nítidos dos traçados, implantação e morfologia originais (REIS, 2004).

Assim, para efeito da análise das matrizes luso-brasileiras no arruamento e ocupação do sítio urbano,

\footnotetext{
7 Remetemos à abordagem propriamente histórico-sociológica, prefigurada pelos pioneiros Donald Pierson e principalmente R. M. Morse, com seu De comunidade a metrópole: Biografia de São Paulo (São Paulo: Comissão do IV Centenário, 1954), reeditado como Formação histórica de São Paulo (São Paulo: Difel, 1970), que chega à maturidade entre os anos 1960 e 1970, nos trabalhos de W. Dean, J. Love e outros. Essa abordagem também desemboca em investigações mais recentes, como aquelas compiladas na coleção História da cidade de São Paulo em quatro volumes, organizada por P. Porta por ocasião dos 450 anos da fundação jesuítica (São Paulo: Paz e Terra, 2004), alguns deles já citados aqui, mas incluindo capítulos como: MESGRAVIS, L. "De bandeirante a fazendeiro: Aspectos da vida social e econômica em São Paulo colonial" (2004); LEMOS, C. A. C. "Notas sobre a cultura material e o cotidiano em São Paulo dos tempos coloniais" (2004b); CAMPOS, A. L. A. "População e sociedade em São Paulo no século XIX" (2004a) e "Vida cotidiana e lazer em São Paulo oitocentista"(2004b); MACHADO, M. H. P. T. "Sendo cativo nas ruas: A escravidão urbana na cidade de São Paulo" (2004); e TEIXEIRA, P. P. “Empreendedores na cidade de São Paulo: Dos primórdios aos grandes empresários” (2004); além de outros capítulos sobre temas específicos como população, religião, ciência, ensino, saúde, artes plásticas, literatura, teatro, música, imprensa, fotografia, cinema, esportes etc.

8 Contraponto entre a história cultural e as transformações urbanas ao longo de quatro séculos e meio encontra-se em CAMPOS, C. M.; GAMA, L. H.; SACCHETTA, W. (Org.). São Paulo: Metrópole em trânsito. Percursos urbanos e culturais. São Paulo: Senac, 2004.
} 
devemos nos concentrar no estudo da situação existente até a primeira metade do século XIX, e identificar seus traços remanescentes sob a ocupação atual. Mesmo com o virtual desaparecimento da ocupação em acrópole de matriz luso-brasileira que presidiu a paisagem paulistana por trezentos anos, podemos considerá-la como marco fundamental na evolução de São Paulo e de sua área central. Sem compreensão acurada dessa região e seus primeiros traços, não podemos identificar adequadamente seus remanescentes, nem propor uma reincorporação, ainda que parcial, da presença da colina na cidade.

\section{Considerações finais}

A urbanística luso-brasileira pode ser caracterizada por um conjunto de parâmetros, normas e práticas que conforma um padrão urbanístico recorrente, caracterizado por determinadas formas de ocupação, arruamento e construção. Pode-se destacar: a preferência pela fundação de núcleos urbanos em locais de topografia dominante, facilmente defensáveis e estrategicamente localizados; para locais à beira-mar, como em Salvador, localização em área protegida à entrada de uma baía ou estuário. Evitava-se a face principal voltada para o alto-mar, pela vulnerabilidade em relação a eventuais ataques marítimos; sítio fundacional situado muitas vezes no local de cota mais baixa do alto da colina, para facilitar a ligação com a cidade baixa; proximidade a um ou mais cursos d'água; boa articulação dos traçados urbanos com as particularidades topográficas locais (ruas, largos, escadas, edifícios singulares).

Como ressalta Manuel Teixeira (2000; 2001), a cidade é projetada no sítio e com o sítio - o seu traçado apenas se concretiza no confronto com a estrutura física natural do território. Nesse sentido, há o predomínio do conhecimento prático sobre o modelo projetual abstrato, que foi justamente o que aconteceu com a implantação da traça que Luis Dias trouxe de Portugal, à colina soteropolitana.

Foi importante o papel dos engenheiros militares e de técnicos arruadores na definição de padrões urbanísticos para quarteirões e ruas. Mas, de maneira geral, esses planos e modelos urbanísticos não eram rígidos: tinham um caráter aberto e flexível, de forma a se adaptarem às circunstâncias, como as condições específicas do sítio, os recursos e técnicas locais, as alterações exigidas ao longo do tempo, e a acomodação dos interesses particulares. Essa atitude não significa necessariamente uma urbanização "espontânea" à margem de regras, ou a ausência de uma visão planejadora. Ao contrário, a aplicação de padrões mais ou menos rigorosos e a presença de claras diretrizes urbanísticas tornam-se uma constante, sobretudo a partir do período pombalino, no século XVIII.

Outro aspecto a destacar é a localização dos edifícios singulares (públicos, militares e de ordens religiosas) em sintonia com a topografia, em locais dominantes, ancorando a estrutura urbana. Tornam-se importantes elementos estruturadores em termos visuais e funcionais. A estruturação da cidade se consolida em núcleos distintos, com características urbanas diferenciadas, correspondendo cada uma a diferentes unidades de crescimento.

Isso se manifesta de forma mais acentuada nos casos em que o núcleo inicial em acrópole passa a ser acompanhado por uma urbanização da região ao sopé da colina, normalmente ligada de modo mais direto às atividades comerciais e portuárias. Tão característico das cidades do universo português, o binômio cidade alta/cidade baixa corresponde a uma divisão funcional, já que a cidade alta costuma manter seu papel residencial e de comando nos campos institucional e religioso, fato verificado tanto na colina paulistana, em relação ao Tamanduateí, quanto em Salvador.

Pode-se salientar ainda o aparecimento tardio das praças urbanas como elementos formais estruturadores do tecido urbano, uma vez que, na sua origem, a cidade portuguesa foi marcada pela presença de largos (em frente às igrejas) e de campos abertos (para manobras militares, festividades, touradas etc.).

Algumas normativas eclesiásticas definiam padrões de localização relevantes para as igrejas: em locais elevados, secos, distante de outras construções e com adro (de modo que as procissões pudessem circular ao redor do edifício), a exemplo da normativa n. 687 das Constituiçoens Primeyras do Arcebispado da Bahia (1853). Também havia a normativa papal que regulamentava o distanciamento mínimo entre as ordens religiosas (conventos e mosteiros) no espaço urbano (cerca de 140 vergas, ou 520 metros). Os jesuítas, porém, estavam isentos dessa regra.

Podemos destacar a importância do papel dos jesuítas na definição do sítio fundacional das cidades 
brasileiras no séc. XVI, como Salvador, São Paulo, Vitória e Rio de Janeiro. Verificamos que os jesuítas preferiam se localizar na beira da escarpa, muitas vezes sobre os trechos mais íngremes. Como as outras ordens, localizavam-se em pontos eminentes, de grande visibilidade e controle. Uma particularidade na presença das ordens religiosas nas capitais brasileiras (jesuítas, carmelitas, beneditinos e franciscanos) envolve certos paralelismos em sua disposição espacial no quadro urbano, visível nos casos de Salvador, São Paulo e Rio de Janeiro. Era distinto o papel estruturador dos conventos (com suas igrejas anexas), daquele representado pela igreja matriz ou Sé, assim como pelas demais igrejas, no âmbito da afirmação do poder religioso no espaço urbano.

Em relação à implantação do edificado no lote, a normativa de construir sem recuos frontais e laterais era comum mais às cidades brasileiras do que às portuguesas. Constatou-se a existência de determinados padrões de medida para a largura das ruas (becos com 15/20 palmos; ruas com 30/40 palmos, e depois com 60 palmos; $25 / 50$ ou $30 / 60$ palmos para a testada dos lotes).

Os "quatro cantos" (únicos cruzamentos ortogonais na malha urbana de muitas cidades) simbolizavam um local de unificação dos espaços religiosos processionais. A "rua direita" é um elemento recorrente, como unificadora de espaços relevantes (entre igrejas, entre a porta principal da muralha e o castelo etc.). É elemento estruturante do espaço urbano que conduz desde o exterior ao edifício mais importante. Após o período medieval, a rua Direita tornou-se um caminho processional que conduzia ao templo. Nem sempre era reta e plana, mas trazia o percurso o mais direto possível, aquele com menos inflexões, em geral com pouca declividade.

Destaca-se a importância das frestas para a garantia da qualidade visual no desfrute da paisagem. Não há como saber, contudo, se esse desfrute visual era uma preocupação da época ou era algo a ser evitado pela lógica da cidade fechada, introvertida, com a construção ao longo de todos os alinhamentos. No século XVI, essas visuais não eram necessariamente intencionais. A partir do século XVIII, pela ótica burguesa, passaram a ser espaços de desfrute. Antes, o melhor local para desfrutar a paisagem era nos edifícios e não na rua.
Tais elementos constituem-se em paradigmas urbanísticos presentes nos principais núcleos urbanos fundados no Brasil ao longo do século XVI, onde Salvador e São Paulo constituem-se em bons exemplos. Esses princípios são advindos de um urbanismo praticado pelos portugueses desde o período medieval, no qual a divisão cidade alta/cidade baixa era a referência, complementada pelas recomendações que mais tarde a engenharia militar daria à defesa das cidades. Em momentos posteriores, durante a União Ibérica e na administração pombalina, nos séculos XVII e XVIII, tais preceitos seriam alterados e passariam a ser substituídos por uma forma urbana marcada pela ortogonalidade no traçado viário e pela maior racionalidade e controle normativo na definição de usos do espaço urbano, tanto público quanto privado.

Propusemos aqui uma recuperação de elementos morfológicos da ocupação original desses sítios, e de compreensão dos padrões urbanísticos que as caracterizavam. Embora sucessivas transformações do núcleo central dessas cidades tenham apagado traços da ocupação em colina de matriz luso-brasileira - alterando traçados, morfologia e volumetria, e ocultando, por vezes, a própria situação topográfica -, importantes impactos dessas práticas permanecem no desenho e na configuração urbanos. Com vistas à revalorização desses elementos históricos, muitas vezes obscurecidos por ocupações posteriores, devemos retraçar e recuperar a forte relação com o sítio original em acrópole que marcou essas cidades.

\section{Referências}

AB'SABER, A. 0 solo de Piratininga. In: BUENO, E. (Org.). Os nascimentos de São Paulo. Rio de Janeiro: Ediouro, 2004.

AMERICANO, J. São Paulo atual (1935-1962). São Paulo: Melhoramentos, 1962a.

AMERICANO, J. São Paulo nesse tempo (1915-1935). São Paulo: Melhoramentos, 1962b.

AMERICANO, J. São Paulo naquele tempo (1895-1915). São Paulo: Melhoramentos, 1962c.

BRUNO, E. S. História e tradições da cidade de São

Paulo. São Paulo: Comissão do IV Centenário, 1954. 
CAMPOS, A. L. A. População e sociedade em São Paulo no século XIX. In: PORTA, P. (Org.). História da cidade de São Paulo: a cidade no Império 1822-1889. São Paulo: Paz e Terra, 2004a. p. 15-55. v. 2.

CAMPOS, A. L. A. Vida cotidiana e lazer em São Paulo oitocentista In: PORTA, P. (Org.). História da cidade de São Paulo: a cidade no Império 1822-1889. São Paulo: Paz e Terra, 2004b. p. 251-305. v. 2.

CAMPOS, C. M.; GAMA, L. H.; SACCHETTA, W. (Org.). São Paulo: Metrópole em trânsito. Percursos urbanos e culturais. São Paulo: Senac, 2004.

CARDIM, F. Narrativa epistolar de uma viagem e missão jesuítica. In: CARDIM, F. Tratados da terra e gente do Brasil. Belo Horizonte: Itatiaia; São Paulo: Edusp, 1980.

CARITA, H. Lisboa manuelina e a formação de modelos urbanísticos da época moderna (1495-1521). Lisboa: Horizonte, 1999.

CENTRO HISTÓRICO DE SALVADOR. Bahia: Patrimônio Mundial. São Paulo: Horizonte Geográfico, 2000.

DEUS, F. G. M. de. Memórias para a história da Capitania de São Vicente. Belo Horizonte: Itatiaia; São Paulo: Edusp, 1975.

FERREZ, G. Bahia, velhas fotografias: 1858-1900. Rio de Janeiro: Kosmos, 1988.

FREITAS, A. A. de. Tradições e reminiscências paulistanas. Belo Horizonte: Itatiaia; São Paulo: Edusp, 1985.

KEHL, L. A. B. Simbolismo e profecia na fundação de São Paulo. São Paulo: Terceiro Nome, 2005.

LEITE, A. História da civilização paulista. São Paulo: Saraiva, 1954.

LEMOS, C. A. C. Organização urbana e arquitetura em São Paulo dos tempos coloniais. In: PORTA, P. (Org.). História da cidade de São Paulo: a Cidade Colonial 1554-1822. São Paulo: Paz e Terra, 2004a. p. 145-177. v. 1.

LEMOS, C. A. C. Notas sobre a cultura material e o cotidiano em São Paulo dos tempos coloniais. In: PORTA, P. (Org.). História da cidade de São Paulo: a Cidade Colonial 1554-1822. São Paulo: Paz e Terra, 2004b. p. 179-189. v. 1.

MACHADO,A.Vidaemortedobandeirante.In:SANTIAGO, S. (Org.). Intérpretes do Brasil. Rio de Janeiro: Nova Aguilar, 2000. p. 1207-1358. v. 1.
MACHADO, M. H. P. T. Sendo cativo nas ruas: a escravidão urbana na cidade de São Paulo. In: PORTA, P. (Org.). História da cidade de São Paulo: a cidade no Império 1822-1889. São Paulo: Paz e Terra, 2004. p. 57-97. v. 2.

MARX, M. Nosso chão: do sagrado ao profano. São Paulo: Edusp, 1989.

MATTOSO, K. M. Q. Bahia: século XIX. Uma província no Império. Rio de Janeiro: Nova Fronteira, 2002.

MESGRAVIS, L. De bandeirante a fazendeiro: aspectos da vida social e econômica em São Paulo colonial. In: PORTA, P. (Org.). História da cidade de São Paulo: a Cidade Colonial 1554-1822. São Paulo: Paz e Terra, 2004. p. 115-143. v. 1.

MILLIET, S. Plantas da cidade. In: COMISSÃO DO IV CENTENÁRIO DA CIDADE DE SÃO PAULO, 1954, São Paulo. Apresentação... São Paulo: Comissão do IV Centenário da Cidade de São Paulo, 1954.

MOREIRA, R. $\mathrm{O}$ arquiteto Miguel de Arruda e o primeiro projeto para Salvador. Cadernos de Pesquisa do LAP, n. $37,2003$.

MORSE, R. M. De comunidade a metrópole: biografia de São Paulo. São Paulo: Comissão do IV Centenário, 1954.

MORSE, R. M. Formação histórica de São Paulo. São Paulo: Difel, 1970.

MOURA, P. C. de. São Paulo de outrora: evocações da metrópole. São Paulo: Martins, 1943.

MOURA, C. E. M. de. (Org.). Vida cotidiana em São Paulo no século XIX: memórias, depoimentos, evocações. São Paulo: Ateliê Editorial, Imprensa Oficial, Unesp, Secretaria da Cultura, 1998.

NÓBREGA, M. da. Cartas do Brasil 1549-1560. Belo Horizonte: Itatiaia; São Paulo: Edusp, 1988.

PINHEIRO, E. P. Europa, França e Bahia. Difusão e adaptação de modelos urbanos (Paris, Rio e Salvador). Salvador: Edufba, 2002.

PITA, S. R. História da América Portuguesa. Belo Horizonte: Itatiaia; São Paulo: Edusp, 1976.

PORTA, P. (Org.). História da cidade de São Paulo: a cidade no Império 1822-1889. São Paulo: Paz e Terra, 2004. v. 2.

PORTO, A. R. História urbanística da cidade de São Paulo. São Paulo: Carthago \& Forte, 1992. 
PRADO Jr., C. O fator geográfico na formação e no desenvolvimento da cidade de São Paulo. In: PRADO Jr., C. Evolução política do Brasil e outros estudos. São Paulo: Companhia das Letras, 2012.

PRADO, P. Paulística etc. Reedição Carlos Augusto Calil. São Paulo: Companhia das Letras, 2004.

REIS FILHO, N. G. Notas sobre o urbanismo barroco no Brasil. Cadernos de Pesquisa do LAP, n. 3, 1994.

REIS FILHO, N. G. Imagens de vilas e cidades do Brasil Colonial. São Paulo: Edusp/Fapesp, 2000.

REIS, N. G. Evolução urbana do Brasil 1500-1720. São Paulo: Pini, 2000.

REIS, N. G. São Paulo: vila, cidade, metrópole. São Paulo: PMSP, 2004.

ROSSA, W. Além da baixa: indícios de planeamento urbano na Lisboa setecentista. Lisboa: Ministério da Cultura, Instituto Português do Patrimônio Arquitectónico, 1998.

SANTOS, M. H. R. dos. A baixa pombalina: passado e futuro. Lisboa: Horizonte, 1999.

SANTOS, P. Formação de cidades no Brasil Colonial. Rio de Janeiro: UFRJ, 2001.

SILVA, J. T. da. São Paulo, 1554-1880: discurso ideológico e organização espacial. São Paulo: Moderna, 1984.

TAUNAY, A. Guia da secção historica do Museu Paulista. São Paulo: Imprensa Official do Estado, 1937.

TAUNAY, A. d'E. História da cidade de São Paulo. São Paulo: Melhoramentos, 1954.

TAUNAY, A. d'E. São Paulo nos primeiros anos. São Paulo: Paz e Terra, 2003.
TEIXEIRA, M. As formas urbanas das cidades portuguesas. Urbanismo de origem Portuguesa, n. 2, Lisboa, set. 2000.

TEIXEIRA, M. Os modelos urbanos portugueses da cidade brasileira. Urbanismo de origem Portuguesa, n. 3, Lisboa, abr. 2001.

TEIXEIRA, M.; VALLA, M. 0 urbanismo português: séculos XIII-XVIII. Portugal-Brasil. Lisboa: Horizonte, 1999.

TEIXEIRA, P. P. Empreendedores na cidade de São Paulo: dos primórdios aos grandes empresários. In: PORTA, P. (Org.). História da cidade de São Paulo: a Cidade Colonial 15541822. São Paulo: Paz e Terra, 2004. p. 271-331. v 1.

TEODORO, J.; RUIZ, R. São Paulo, de vila a cidade: a fundação, o poder público, a vida política. In: PORTA, P. (Org.). História da cidade de São Paulo: a Cidade Colonial 1554-1822. São Paulo: Paz e Terra, 2004. v. 1. p. 69-113.

TOLEDO, B. L. de. São Paulo: três cidades em um século. São Paulo: Duas Cidades, 1983.

UNIVERSIDADE FEDERAL DA BAHIA/FUNDAÇÃO GREGÓRIO DE MATOS. Evolução Física de Salvador (1549-1800). Salvador: Pallotti, 1998.

VIDE, S. M. da. (Org.). Constituições Primeiras do Arcebispado da Bahia. São Paulo, 1853. (Typ. 2).

Recebido: 05/06/2012

Received: 06/05/2012

Aprovado: 24/10/2012

Approved: 10/24/2012 